\title{
Hydrological Responses of Headwater Basins to Monthly Perturbed Climate in the North American Cordillera
}

\author{
KABIR RASOULI \\ Department of Geoscience, University of Calgary, Calgary, Alberta, and Centre for Hydrology, \\ University of Saskatchewan, Saskatoon, Saskatchewan, Canada \\ JOHN W. POMEROY \\ Centre for Hydrology, University of Saskatchewan, Saskatoon, Saskatchewan, Canada \\ PAUL H. WHITFIELD \\ Centre for Hydrology, University of Saskatchewan, Saskatoon, Saskatchewan, and Environment and \\ Climate Change Canada, Vancouver, British Columbia, Canada
}

(Manuscript received 9 August 2018, in final form 16 February 2019)

\begin{abstract}
How mountain hydrology at different elevations will respond to climate change is a challenging question of great importance to assessing changing water resources. Here, three North American Cordilleran snowdominated basins-Wolf Creek, Yukon; Marmot Creek, Alberta; and Reynolds Mountain East, Idaho-each with good meteorological and hydrological records, were modeled using the physically based, spatially distributed Cold Regions Hydrological Model. Model performance was verified using field observations and found adequate for diagnostic analysis. To diagnose the effects of future climate, the monthly temperature and precipitation changes projected for the future by 11 regional climate models for the mid-twenty-first century were added to the observed meteorological time series. The modeled future was warmer and wetter, increasing the rainfall fraction of precipitation and shifting all three basins toward rainfall-runoff hydrology. This shift was largest at lower elevations and in the relatively warmer Reynolds Mountain East. In the warmer future, there was decreased blowing snow transport, snow interception and sublimation, peak snow accumulation, and melt rates, and increased evapotranspiration and the duration of the snow-free season. Annual runoff in these basins did not change despite precipitation increases, warming, and an increased prominence of rainfall over snowfall. Reduced snow sublimation offset reduced snowfall amounts, and increased evapotranspiration offset increased rainfall amounts. The hydrological uncertainty due to variation among climate models was greater than the predicted hydrological changes. While the results of this study can be used to assess the vulnerability and resiliency of water resources that are dependent on mountain snow, stakeholders and water managers must make decisions under considerable uncertainty, which this paper illustrates.
\end{abstract}

\section{Introduction}

Snow and its seasonal dynamics play a key role in freshwater availability in mountainous regions. Mountainous areas contribute much of the total discharge of a watershed (Meybeck et al. 2001; Viviroli and Weingartner 2004). With warmer temperatures and changing precipitation patterns expected in the future, substantial hydrological changes are expected in mountains and basins with near-freezing winter temperatures as precipitation

Corresponding author: Kabir Rasouli, kabir.rasouli@usask.ca shifts from snowfall to rainfall (Running and Nemani 1991; Rango 1992; Leith and Whitfield 1998; Hamlet and Lettenmaier 1999; Leung and Ghan 1999). Changing future snow dynamics in mountain watersheds, where snowpack development and runoff generation are changing to varying degrees at different elevations, makes the hydrological response complicated (López-Moreno et al. 2014). High spatial heterogeneity in mountains leads to large uncertainties in observed data and models (Klemeš 1990). Further, modeling mountain hydrology is challenging because monitoring at high elevations is sparse and records are often incomplete (Klemeš 1990; 
Mote et al. 2005; Hrachowitz and Weiler 2011; Naz et al. 2014; 2016).

There are many sources of uncertainty embedded within projections of future hydrological conditions. These include (i) greenhouse gas emission scenarios (Bennett et al. 2012), (ii) choice of hydrological model (Bennett et al. 2012), (iii) choice of observed data (Elsner et al. 2014), (iv) complexity in orographic regions (Barry 1992), (v) biases when comparing observations with climate simulations for the control period (Fowler et al. 2007), and (vi) change in large-scale climate signals including El Niño-like conditions and cold weather outbreaks (Timmermann et al. 1999). The uncertainty regarding large-scale changes in climate variability can be pronounced (Trenberth 1990; Mann et al. 1995; Deser et al. 2012; Boé and Habets 2014), especially in small hydrological basins with short-term simulations that do not capture interannual or decadal variations (Wunsch 1999; Blöschl et al. 2007; Poulin et al. 2011). A full range of uncertainties related to observations, climate change forcing data, model structure and parameters, and calibrating and downscaling methods makes hydrological modeling of mountains very challenging. Bennett et al. (2012) quantified uncertainties from all sources for winter runoff anomalies in the 2050s from GCMs (84\%), emissions scenarios (58\%), and hydrological parameterization $(31 \%)$ in mountainous basins in British Columbia, Canada. The uncertainty in different forcing datasets are large in mountains, which might be related to the high spatial variability of precipitation and temperature in mountains and the use of fixed lapse rates with elevation for extrapolation of point measurements (Klemeš 1990; Elsner et al. 2014; Seyyedi et al. 2014). Here, the range of hydrological uncertainty due to climate model uncertainty (width of the spread around mean of the ensemble) is contrasted against the range of differences between current and future hydrological conditions due to climate change (where future conditions are represented by the mean of the ensemble of hydrological responses) using a single hydrological model for three basins.

One issue with hydrological applications of GCMs or coupled RCM-GCMs, is that they do not appropriately capture hydrologically important climate processes (i.e., El Niño) and structures (e.g., Robertson and Mechoso 1998; Wang et al. 2006; Guilyardi et al. 2004; Ouachani et al. 2013). There are many studies that applied bias-corrected GCM and RCM outputs to examine changes in hydrology (e.g., Hidalgo and Dracup 2003; Wood et al. 2004; Teutschbein and Seibert 2012). Statistical downscaling of large-scale atmospheric circulations from GCMs to high-resolution variables at local scale is one widely used approach (e.g., Cannon 2008; Hsieh 2009; Maraun et al. 2010; Gaitan et al. 2014; Gutmann et al. 2014). A second approach to adequately represent alpine terrain is higher resolution through dynamical downscaling that uses GCM outputs to set the boundary conditions of regional climate models to provide regional-scale circulation fields consistent with those obtained from GCMs (e.g., Mearns et al. 2007; Maples et al. 2014); however, dynamical downscaling approaches are computationally expensive (Hijmans et al. 2005; Gutmann et al. 2016).

One alternative to statistical and dynamical downscaling methods is the delta change factor approach (e.g., Stockton and Boggess 1979; Semadeni-Davies et al. 2008; Kawase et al. 2009), which can be used to produce plausible hydroclimatological changes to represent future conditions. The delta change factor method uses the differences in monthly climatology between modeled current and future climates for precipitation and air temperature (Stockton and Boggess 1979) and applies those differences to meteorological observations. The perturbation method used here combines long-term specialized, multiple elevation, hourly observations from mountain research basins with monthly deltas from 11 North American Regional Climate Change Assessment Program (NARCCAP) members using SRES A2 greenhouse gas emission scenario to capture a physical representation of the climate and hydrology at high temporal resolution and at multiple elevations. This is a unique approach that has not been previously explored.

Snow regime and snowmelt runoff timing in lowelevation basins with near-freezing air temperatures are more sensitive to warming than high-elevation basins with winter temperatures well below the freezing point (Stewart et al. 2004; Nayak 2008). Hydrological sensitivity of mountain basins to a warming climate depends on elevation and consequently to winter temperatures (Stewart et al. 2004) and, hence, low-elevation basins are more susceptible to climatic changes. Both elevational (e.g., Knowles and Cayan 2004) and latitudinal hydrological sensitivities (Nijssen et al. 2001) to a warming climate are examined here. This paper is organized as following: In section 2, the study basins and methodology are described; physically based modeling of mountain hydrological processes is introduced; and the first-order impacts of changing climate on mountain hydrology using a perturbation of high-elevation weather data based on monthly changes in RCM outputs are demonstrated. The results are presented in section 3 and are discussed in section 4, and finally, the summary and conclusions are in section 5 . 
TABLE 1. Meteorological data measured in three sites in the basin including variables, climatological water year mean values, current sensors, and measurement height. The link to access to long-term datasets and descriptions for each basin were provided in Rasouli et al. (2019), Fang et al. (2019), and Reba et al. (2011).

\begin{tabular}{|c|c|c|c|}
\hline Variable & Site & Site/gauge latitude, longitude & Record period \\
\hline \multirow[t]{12}{*}{ Precipitation $(\mathrm{mm})$} & WCRB & Alpine: $60^{\circ} 31.34^{\prime} \mathrm{N}, 135^{\circ} 11.84^{\prime} \mathrm{W}$ & 1993-2011 daily \\
\hline & & Shrub tundra: $60^{\circ} 34.04^{\prime} \mathrm{N}, 135^{\circ} 08.98^{\prime} \mathrm{W}$ & \\
\hline & & Forest: $60^{\circ} 35.76^{\prime} \mathrm{N}, 134^{\circ} 57.17^{\prime} \mathrm{W}$ & \\
\hline & MCRB & Centennial Ridge: $50^{\circ} 56.68^{\prime} \mathrm{N}, 115^{\circ} 11.62^{\prime} \mathrm{W}$ & 2005-14 hourly \\
\hline & & Fisera Ridge: $50^{\circ} 57.42^{\prime} \mathrm{N}, 115^{\circ} 12.27^{\prime} \mathrm{W}$ & \\
\hline & & Vista View: $50^{\circ} 58.25^{\prime} \mathrm{N}, 115^{\circ} 10.33^{\prime} \mathrm{W}$ & \\
\hline & & Upper clearing: $50^{\circ} 57.40^{\prime} \mathrm{N}, 115^{\circ} 10.52^{\prime} \mathrm{W}$ & \\
\hline & & Upper forest: $50^{\circ} 57.42^{\prime} \mathrm{N}, 115^{\circ} 10.57^{\prime} \mathrm{W}$ & \\
\hline & & Hay meadow: $50^{\circ} 56.63^{\prime} \mathrm{N}, 115^{\circ} 08.38^{\prime} \mathrm{W}$ & \\
\hline & & Level forest: $50^{\circ} 56.78^{\prime} \mathrm{N}, 115^{\circ} 08.80^{\prime} \mathrm{W}$ & \\
\hline & RME & Sheltered: $43^{\circ} 11.16^{\prime} \mathrm{N}, 116^{\circ} 46.98^{\prime} \mathrm{W}$ & 1983-2008 hourly \\
\hline & & Exposed: $43^{\circ} 11.15^{\prime} \mathrm{N}, 116^{\circ} 47.01^{\prime} \mathrm{W}$ & \\
\hline \multirow[t]{4}{*}{ Air temperature $\left({ }^{\circ} \mathrm{C}\right)$ and humidity $(\%)$} & WCRB & Alpine, shrub tundra, forest & 1993-2011 hourly \\
\hline & MCRB & $\begin{array}{l}\text { Centennial Ridge, Fisera Ridge, Vista View, upper clearing, } \\
\text { Upper forest, hay meadow, level forest }\end{array}$ & 2005-14 hourly \\
\hline & RME & Sheltered & 1983-2008 hourly \\
\hline & & Exposed & \\
\hline \multirow{4}{*}{ Wind speed $\left(\mathrm{m} \mathrm{s}^{-1}\right)$ and direction } & WCRB & Alpine, shrub tundra, forest & 1993-2011 hourly \\
\hline & MCRB & $\begin{array}{l}\text { Centennial Ridge, Fisera Ridge, Vista View, upper clearing, } \\
\text { upper forest, hay meadow, level forest }\end{array}$ & 2005-14 hourly \\
\hline & RME & Sheltered & 1983-2008 hourly \\
\hline & & Exposed & \\
\hline \multirow[t]{3}{*}{ Snow water equivalent (mm) } & WCRB & Alpine, shrub tundra, forest & 1993-2011 monthly \\
\hline & MCRB & Fisera Ridge top, Fisera Ridge south, upper clearing & 2005-14 monthly \\
\hline & RME & Sheltered & 1983-2008 hourly \\
\hline \multirow[t]{3}{*}{ Streamflow $\left(\mathrm{m}^{3} \mathrm{~s}^{-1}\right)$} & WCRB & Alaska Highway: $60^{\circ} 36.00^{\prime} \mathrm{N}, 134^{\circ} 57.00^{\prime} \mathrm{W}$ & 1993-2011 hourly \\
\hline & MCRB & Water survey: $50^{\circ} 57.03^{\prime} \mathrm{N}, 115^{\circ} 09.17^{\prime} \mathrm{W}$ & 2005-14 hourly \\
\hline & RME & Outlet: $43^{\circ} 11.17^{\prime} \mathrm{N}, 116^{\circ} 46.98^{\prime} \mathrm{W}$ & 1983-2008 hourly \\
\hline
\end{tabular}

\section{Study areas and methodology}

\section{a. Study areas and data sources}

Potential hydrological responses to warming and precipitation changes in three headwater basins from three latitudes of the North American Cordillera are examined. Information about the observational data, number of stations available in each basin, hydrometeorological variables recorded at each station, and the time period of the observations for each basin are provided in Table 1 . The three study basins include:

1) Wolf Creek Research basin (WCRB; $\approx 61^{\circ} \mathrm{N}, 179 \mathrm{~km}^{2}$ ), Yukon Territory, Canada, a subarctic headwater basin (Fig. 1a) with a long cold snow season with little precipitation (Fig. 2a). At low elevations in WCRB are lodgepole pine, white spruce, and trembling aspen forest stands (Francis et al. 1999). Above the treeline, shrub tundra with dwarf birch and willow shrub heights from $30 \mathrm{~cm}$ to $2 \mathrm{~m}$ occupies the majority of the basin $(65 \%)$. At the highest elevations in WCRB are bare rock, short tundra mosses, and grasses. Lewkowicz and Ednie (2004) estimate that $43 \%$ of WCRB contains permafrost. When soil freezes it restricts the movement of water beneath the surface, particularly in the case of saturated frozen soils (Carey and Woo 2001; Quinton et al. 2009; Williams et al. 2015).

2) Marmot Creek Research basin (MCRB; $\approx 51^{\circ} \mathrm{N}$, $9.4 \mathrm{~km}^{2}$ ), Alberta, Canada, a headwater basin of the Bow River in the Front Ranges of the Canadian Rocky Mountains (Fig. 1b) has a cold snow season with high precipitation (Fig. 2b). This leads to long winters particularly at high elevations, and warmer air temperatures (Fig. 2b) with fewer freezing days at lower elevations. Vegetation in the forested portion of MCRB is mainly Engelmann spruce and alpine fir at the higher elevations and lodgepole pine at the lower elevations (Kirby and Ogilvie 1969). Short shrubs and alpine larch are found near the treeline. Above 2250-m elevation, only exposed rocks and talus are present. Soils freeze seasonally in MCRB.

3) Reynolds Mountain East catchment $\left(\mathrm{RME} ; \approx 43^{\circ} \mathrm{N}\right.$, $0.39 \mathrm{~km}^{2}$ ), Idaho, United States, is a seasonally cool, montane headwater basin (Fig. 1c). In contrast to the two other basins, RME has warmer air temperatures 


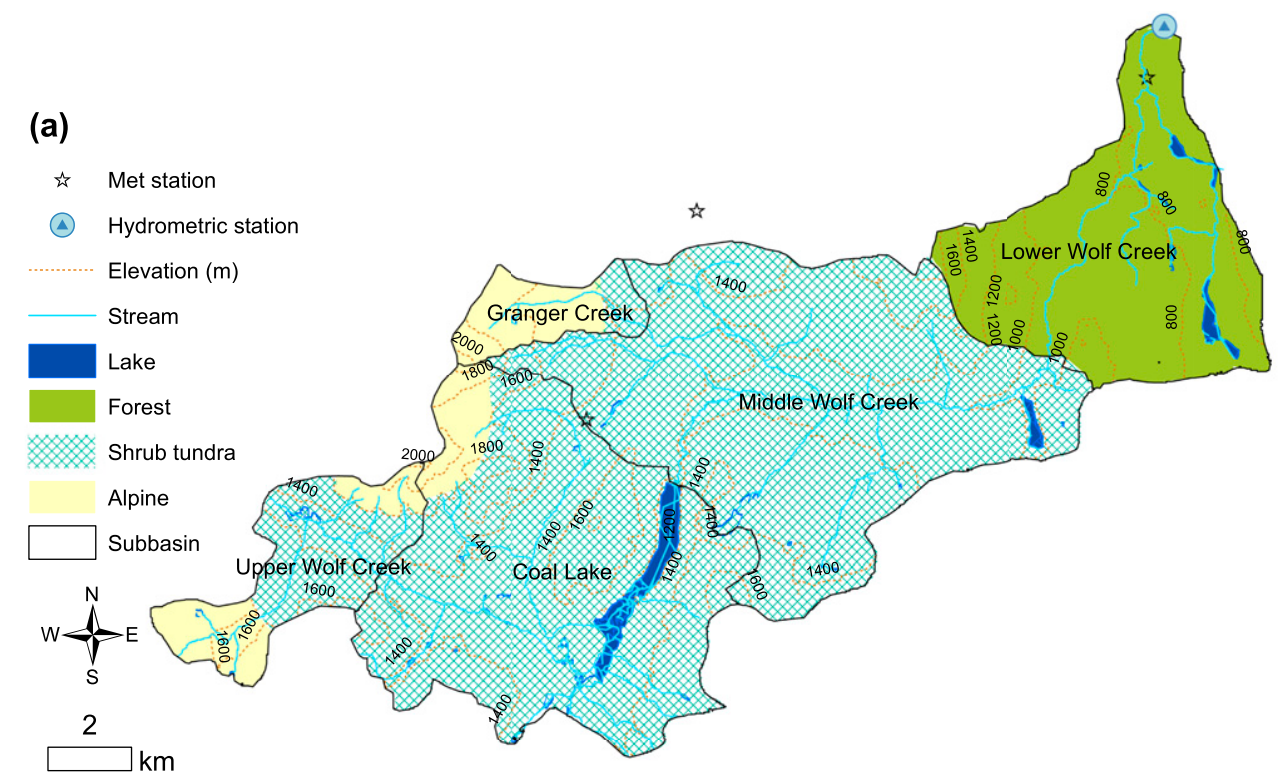

(b)

(i) Met station

(4) Hydrometric station

Elevation $(\mathrm{m})$

Stream
Forest
Treeline
Forest clearin
Alpine
Subbasin

(c)

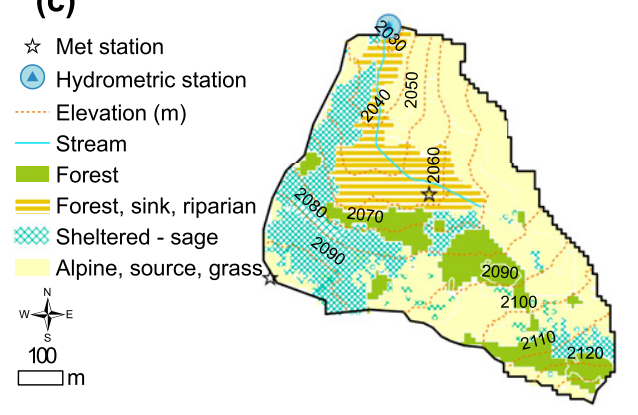

FIG. 1. Three headwater basins across the Western North American Cordillera: (a) Wolf Creek Research basin (WCRB), Yukon Territory, with five subbasins; (b) Marmot Creek Research basin (MCRB), Alberta, with four subbasins; and (c) Reynolds Mountain East (RME) catchment, a subbasin within Reynolds Creek Experimental Watershed, Idaho, United States. There are three, seven, and two meteorological stations, respectively in WCRB, MCRB, and RME. Areal coverage of the main biomes in each basin studied in this research are shown.

with fewer freezing days (Fig. 2c) despite being at a higher elevation. Six main vegetation types are present in RME; grasses, mountain sagebrush, riparian willow, trembling aspen, Douglas fir, and bare ground (Seyfried et al. 2009; Kumar et al. 2013;
Winstral and Marks 2014). Grasses dominate dry meadows in RME. Trembling aspen trees are located in topographic depressions on hillsides that tend to fill with wind-blown snowdrifts. Soils do not freeze during the year in RME. 


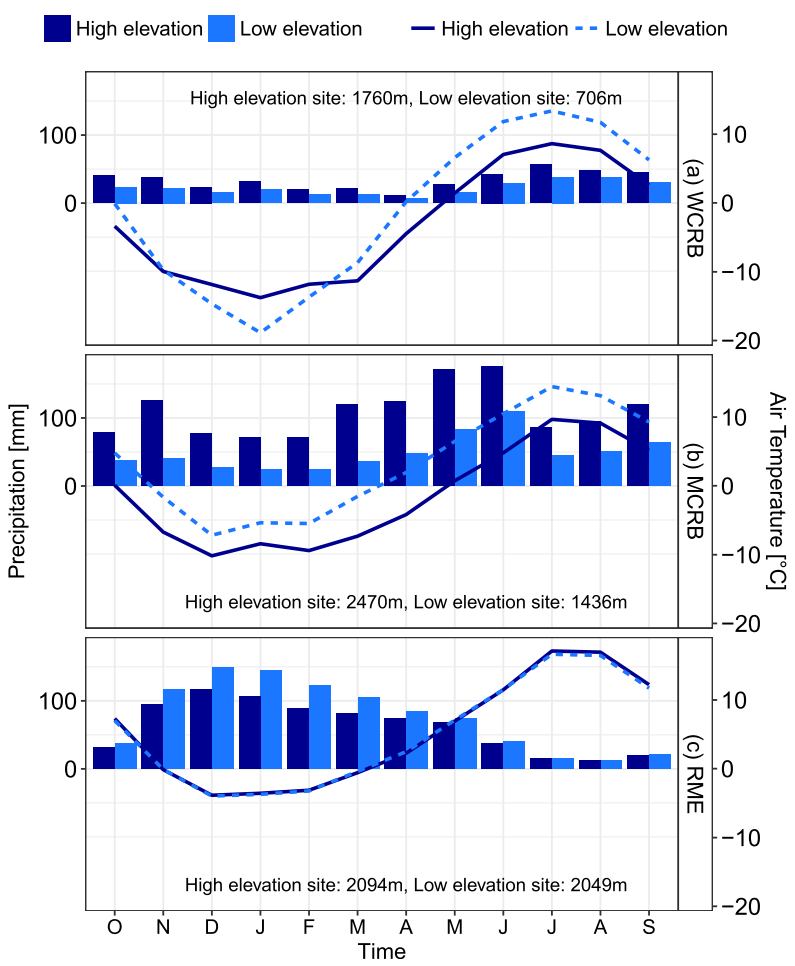

FIG. 2. Seasonal variation in precipitation (bars) and air temperature (lines) at two high- and low-elevation stations in (a) WCRB, (b) MCRB, and (c) RME. RME has a small drainage area, and air temperatures at the two stations are similar. Most of precipitation falls as rain in summer months in WCRB, and as snow in fall and winter in RME. The cold season starts in October and lasts until May at high elevations in MCRB, and most snow falls from March to June.

These three basins are useful case studies for comparing and contrasting the hydrological processes under climate changes across the North American Cordillera based upon representing multiple biomes in each basin and the availability of long-term data from stations at multiple elevations. Precipitation was measured by tipping-bucket rain gauges, unshielded "BC style standpipe" precipitation gauges, and Nipher-shielded Meteorological Service of Canada (MSC) snowfall gauges in WCRB, by an Alter-shielded Geonor weighing gauge in MCRB, and by both shielded and unshielded weighing gauges in RME. Precipitation measurements were corrected using a wind undercatch correction equation (Goodison et al. 1998) with wind speeds measured from nearby gauge-height anemometers. High-quality measurements of hourly air temperature $(\mathrm{Ta})$, relative humidity $(\mathrm{RH})$, wind speed $(u)$, incoming shortwave radiation $(\mathrm{SW})$, precipitation $(P)$ observations, and streamflow data for each basin are used in this study.

\section{b. Modeling strategy and methods: Present climate}

The methodological steps in this study include the following:
1) Set up, test, and validate hydrological models developed from the Cold Regions Hydrological Modeling (CRHM) platform (Pomeroy et al. 2007, 2016). CRHM is used to create distributed models that use many hydrological response units to discretize the basin. For large basins, CRHM models are run with hydrological response units (HRUs) within subbasins. CRHM is modular and so there is flexibility in the sets of algorithms, called modules, chosen for calculating various hydrological processes. CRHM interpolates observation data from stations or gridcell points to the HRU by lapsing temperature, humidity, and precipitation and also adjusts wind speed using a complex terrain windflow calculation. Precipitation phase and longwave irradiance are further adjusted by elevation, temperature, and humidity interpolations, and shortwave irradiance is adjusted by slope and aspect. It uses vegetation characteristics to further adjust surface variables and fluxes for various hydrological flux calculations.

2) Conduct uncertainty analyses using these models driven by perturbed observations.

3) Compare the water balance and hydrological regime metrics between monthly perturbed and observed climates to estimate the range of modeling uncertainties between the deltas from different RCMs.

The setting up, testing, and validating of models using CRHM consisted of selecting a set of physically based modules describing the major processes informed by results from previous modeling experiments in the three research basins: WCRB (Pomeroy et al. 1999, 2003, 2006; McCartney et al. 2006; Carey et al. 2007; Dornes et al. 2008; Quinton and Carey 2008; MacDonald et al. 2009; Rasouli et al. 2014), MCRB (Pomeroy et al. 1998, 2012, 2015, 2016; Ellis et al. 2010, 2011; MacDonald 2010; Fang et al. 2013; Williams et al. 2015; Fang and Pomeroy 2016), and RME (Link et al. 2004; Flerchinger et al. 2012; Reba et al. 2012, 2014; Winstral et al. 2013). Modules for sublimation and snow redistribution by blowing wind were used in this study and blowing snow regimes are investigated in alpine areas. These hydrological processes increase with increasing wind speed in complex terrain, which can lead to large variations in snow depth and snowmelt (Essery et al. 1999). For more details of the modules selected refer to Rasouli et al. (2014) and Rasouli (2017). The energy balance snowmelt model was developed in the alpine region of the Sierra Nevada (Marks and Dozier 1992) and tested in RME catchment (Marks et al. 1998) and the Canadian Rockies (DeBeer and Pomeroy 2010).

Basic characteristics of the study areas, including the dominant land cover, elevation of representative stations, 


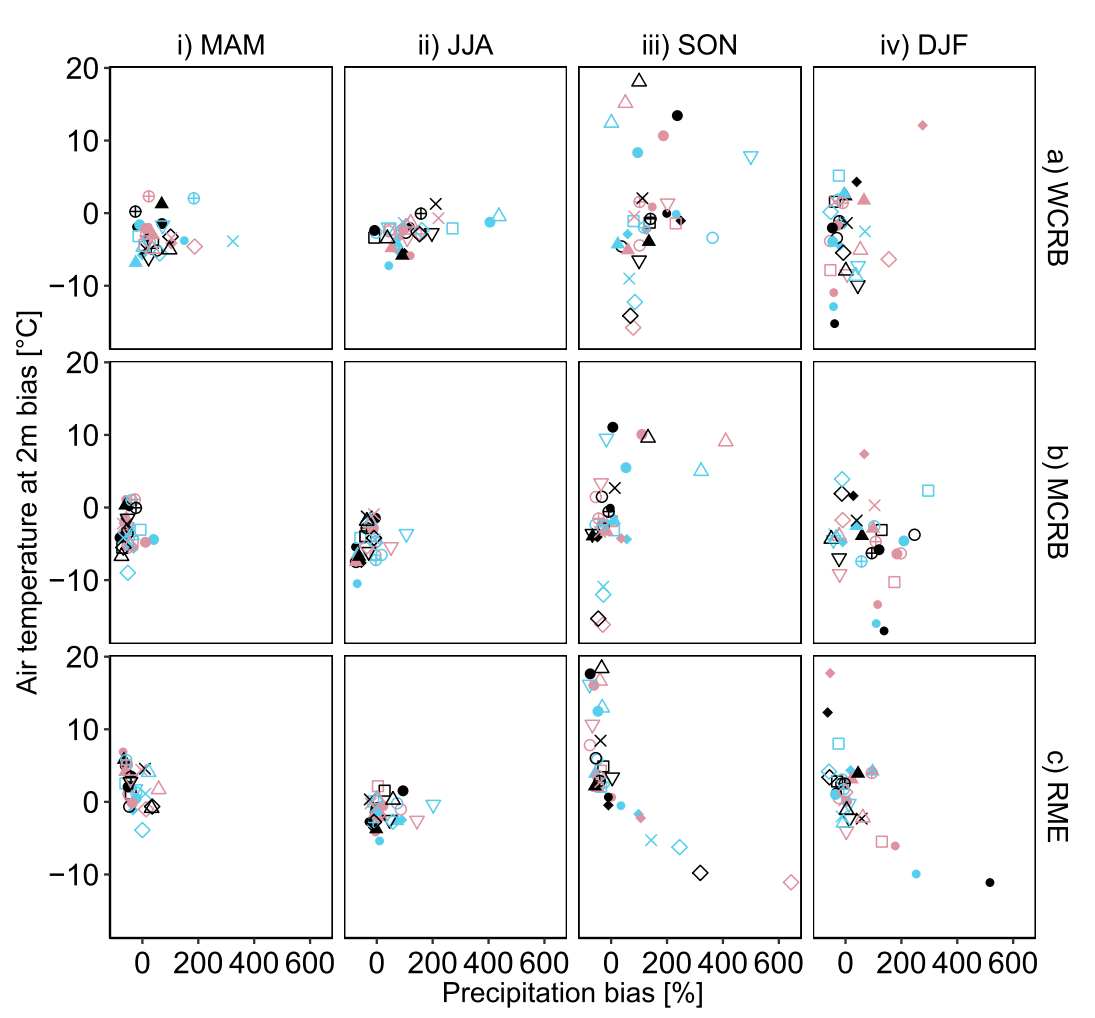

Months

- 1

- 2

- 3

- 4

- 5

- 6

- 7

- 8

- 9

- 10

- 11

- 12

RCMs

- CRCM-ccsm

- CRCM-cgcm3

$\triangle$ ECP2-gfdl

$\times$ HRM3-gfdl

$\diamond$ HRM3-hadcm3

- MM5I-ccsm

$\nabla$ MM5I-hadcm3

$\oplus$ RCM3-cgcm3

- RCM3-gfdl

- WRFG-ccsm

- WRFG-cgcm3

FIG. 3. Precipitation and air temperature biases between measurements at a meteorological station in each of the three headwater basins across the North American Cordillera and outputs from 11 RCM-GCMs. In each panel, the monthly bias for each of the three months is shown for each of the RCMs.

and soil types, are used to parameterize the hydrological models. Three elevation bands (high, middle, and low elevation, respectively) reflecting three biomes in WCRB and four in MCRB are included in the model. Because RME has the highest average elevation but smallest elevation range, it is only comparable to the high-elevation bands and alpine biomes in the other two basins. The resulting spatially distributed modeling structures had five subbasins and 29 HRUs in WCRB, four subbasins and 36 HRUs in MCRB, and one subbasin and 12 HRUs in RME in order to capture differences in elevation, slope, aspect, and vegetation. All the HRUs were categorized into either one of the biome groups or the blowing snow regimes for parsimonious parameterization. Snow water equivalent (SWE) was modeled for each HRU and biome in the three basins and compared against observations. The wind redistribution by blowing snow between the HRUs and blowing snow sublimation losses throughout the winter period were simulated by the blowing snow model in CRHM (Pomeroy et al. 1993; Pomeroy and Li 2000; MacDonald et al. 2009, 2010). Wind speed variations were estimated based on reference observations from stations or gridcell points interpolated to the HRU using a complex terrain boundary layer model that takes into account topographic features, and aerodynamic roughness changes (Walmsley et al. 1989).

\section{c. Modeling strategy and methods: Perturbed climate}

Comparing mountain weather observations and RCM outputs for the current period showed large biases (Fig. 3); differences between observations and RCM outputs for each watershed and all months were considerable. The variation in the biases was much greater in cold months (September-March). The RCMs overestimated precipitation, air temperatures, and the number of dry days (Rasouli 2017) and did not capture local mountain precipitation processes associated with orography and convection. Dynamical downscaling of a GCM by RCMs to scales of tens of kilometers is insufficient to capture the local-scale processes such as storm dynamics, or in the length of wet or dry spells that are critical to capturing the hydrology of these mountain basins. Therefore, the direct application, even with bias correction of the RCM outputs, may not capture the spatial and temporal patterns of observed hydrometeorological processes. Using unrealistic climate change forcing data would introduce unnecessary uncertainty 
TABLE 2. The 11 RCMs used from the NARCCAP project (Mearns et al. 2007) for determining the monthly perturbation of climate, along with their driving GCMs. The RCMs cover a wide range of the climate model uncertainty.

\begin{tabular}{lll}
\hline \hline \multicolumn{1}{c}{ RCM } & \multicolumn{1}{c}{ Driving GCM } & \multicolumn{1}{c}{ RCM-GCM } \\
\hline $\begin{array}{l}\text { Weather Research and Forecasting Model updated } \\
\text { Grell configuration } \\
\text { Weather Research and Forecasting Model updated } \\
\quad \text { Grell configuration }\end{array}$ & Community Climate System Model & WRFG-CCSM \\
Canadian Regional Climate Model & Canadian Global Climate Model 3 & WRFG-CGCM3 \\
Canadian Regional Climate Model & Community Climate System Model & CRCM-CCSM \\
Regional Climate Model version 3 & Canadian Global Climate Model 3 & CRCM-CGCM3 \\
$\begin{array}{l}\text { Regional Climate Model version 3 } \\
\text { PSU/NCAR mesoscale model }\end{array}$ & Geophysical Fluid Dynamics Laboratory & RCM3-GFDL \\
PSU/NCAR mesoscale model & Canadian Global Climate Model 3 & RCM3-CGCM3 \\
Hadley Regional Model 3 & Community Climate System Model & MM5I-CCSM \\
Hadley Regional Model 3 & Hadley Centre Coupled Model 3 & MM5I-HadCM3 \\
Experimental Climate Prediction-2 & Hadley Centre Coupled Model 3 & HRM3-HadCM3 \\
\hline
\end{tabular}

into the subsequent hydrological modeling. This uncertainty can be avoided by preserving the observed meteorological patterns and perturbing them with the modeled future changes as described below. For hydrological modeling, the preservation of the structure of observed meteorological conditions results in realistic weather patterns and internal consistency; this makes this method preferable. Conceptually, this method is similar to the pseudo-global warming method where the boundary and initial conditions of high-resolution weather forecasting models are perturbed to generate dynamically downscaled climate model predictions (Schär et al. 1996; Kawase et al. 2009). Its limitation is that it can only be performed for heavily instrumented research basins where there are long, spatially detailed weather records available. Eleven RCM-GCM outputs from NARCCAP (Table 2) were used to determine the monthly differences between future and present temperature and precipitation and capture the variability among the RCM-GCMs; relative humidity was kept constant to allow vapor pressure to increase with warming of air temperature; the modeled current (1971-2000) monthly 30-yr climatological averages were subtracted from the modeled future (2041-70) monthly 30-yr climatological averages. These differences (delta) are referred to here as monthly perturbed climate (MPC); differences between modeled present and future are noisy at small time steps, and monthly differences were felt to be a reasonable time period to capture seasonal variations. Some of the limitations of the delta method include that the method assumes RCM-GCM outputs for modeled present and future climates show relative changes rather than absolute changes, hence the number, pattern and structure of weather events are the same in both current and future perturbed climate forcings (Semadeni-Davies et al. 2008), all wet events become wetter, and only the monthly magnitude of temperature and precipitation are changed. Not all potential changes in variability are captured using this method and there is a magnitude shift in the distribution of precipitation and the distribution of the severity of events due to the delta, but not to their timing. These might add some uncertainty on snowpack, evapotranspiration, and runoff processes.

\section{d. Significance testing}

The Mann-Whitney $U$ test (Wilcoxon 1945; Mann and Whitney 1947) was used to test the significance of the changes in distribution of the simulated variables. The Mann-Whitney $U$ test is a nonparametric test for equality of distributions of two independent samples. Simulated distributions with $n=18$ years for WCRB, 9 years for MCRB, and 25 years for RME over the control (baseline) period for each hydrological variable were compared with the simulated future distributions obtained from 11 RCM-GCMs $(11 \times n$ values $)$. Assuming a standard normal distribution, the $95 \%$ confidence intervals for the interannual variability of snow and streamflow were calculated based on standard deviation $\sigma$ and sample of size $n$ using the following equation:

$$
\bar{X} \pm 1.96 \frac{\sigma}{\sqrt{n}}
$$

where $\bar{X}$ is the population mean around which the confidence intervals were calculated and 1.96 is the critical value for $z_{\alpha}^{*}$ with $\alpha=95 \%$.

\section{e. Assessment of hydrological model performance}

Simulated SWE is compared against observations in three biomes in WCRB and MCRB, and in the sheltered site in RME (Fig. 4). The energy balance snowmelt model simulates snow regime better in RME, where it was developed, than in the other two basins. In RME the snowpack is shallow and temperate compared to the 


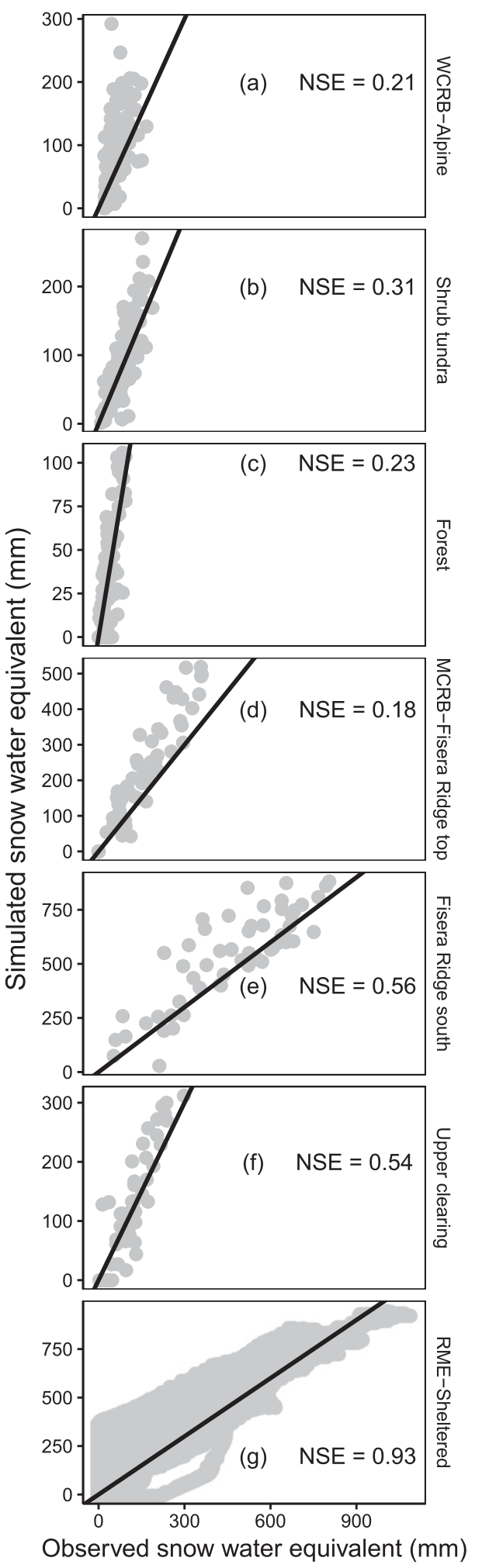

FIG. 4. Performance of the CRHM in capturing SWE for three stations representing three biomes in WCRB (a) alpine, (b) shrub tundra, and (c) forest, three in MCRB (d) Fisera Ridge top, (e) Fisera Ridge south facing slope, and (f) upper clearing stations, and $(\mathrm{g})$ a snow pillow in the wind sheltered site in RME. The $y$ axis colder deeper snowpacks in Canadian basins (Table 3). Models slightly overestimate the snowpack, especially in the alpine biomes despite the use of blowing snow modules (Table 3). In WCRB, simulated snowpack in the forest and shrub tundra biomes had a low root-mean-square error (RMSE), mean absolute error (MAE), and normalized mean bias error (NMBE), and peak SWE was slightly overestimated in the alpine and shrub tundra biomes (Figs. 4a,b). In MCRB, peak SWE was slightly overestimated at the Fisera Ridge top and Fisera Ridge south facing stations (Figs. 4d,e). In RME, peak SWE was slightly overestimated in the sheltered station which is sheltered from blowing snow (Fig. 4g). The overall performance of the uncalibrated snow model is encouraging. High spatial variability of wind speed and wind direction might be a reason for the slight overestimation of snowpack in the alpine biomes in WCRB and MCRB. Considering the complexity of the processes and high spatial variability of hydrometeorological variables in headwater basins, the performance of the models in capturing the snow regime in the three basins is considered good and based on these models a reliable sensitivity analysis of snow regimes can be conducted.

The accuracy of hydrological model performance in simulating streamflow depends mainly on the accuracy of snow accumulation and ablation simulation and the soil temperature and moisture modeling, which affect infiltration and subsurface flows. Comparing the observed and simulated runoff at the gauged outlet of the basins for each basin tests the performance of the models (Fig. 5). The models for WCRB and RME were minimally calibrated and the MCRB model was uncalibrated. Calibration was restricted to a few parameters dealing with subsurface storage and routing and used the dynamically dimensioned search approach (Tolson and Shoemaker 2007) with 3-4 years of data so as not to overfit the models. Statistical performance measures (Table 4) show that the RME model simulated runoff better than the other two models, and that the WCRB model had only a moderate performance. The NashSutcliffe efficiency (NSE) scores for 3- and 4-yr calibration periods for WCRB and RME are 0.64 and 0.73 , respectively (Table 4). The NSE scores for 8 and 25 years of streamflow simulations in MCRB and RME are 0.72 and 0.71 , respectively, which shows that the CRHM captures mountain hydrology, except for some high flow events, within a reasonable range of simulation errors.

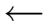

has different scales for different subplots. The line has a 1:1 slope, which indicates that the models slightly overestimate the SWE in some biomes. No calibration is applied in snowpack simulation. 
TABLE 3. Model performance statistics in simulating snowpack in the three basins across the North American Cordillera.

\begin{tabular}{|c|c|c|c|c|c|c|c|}
\hline \multirow[b]{2}{*}{ Criteria } & \multicolumn{3}{|c|}{ WCRB } & \multicolumn{3}{|c|}{ MCRB } & \multirow{2}{*}{$\frac{\text { RME }}{\text { Sheltered site }}$} \\
\hline & Alpine & Shrub tundra & Forest & Fisera Ridge top & Fisera Ridge south & Upper clearing & \\
\hline Correlation (unitless) & 0.74 & 0.81 & 0.73 & 0.93 & 0.85 & 0.88 & 0.98 \\
\hline $\operatorname{RMSE}(\mathrm{mm})$ & 35 & 34 & 19 & 90 & 131 & 45 & 56 \\
\hline $\operatorname{MAE}(\mathrm{mm})$ & 28 & 26 & 14 & 70 & 97 & 34 & 29 \\
\hline NMBE (unitless) & -0.47 & -0.06 & 0.05 & -0.41 & -0.14 & -0.08 & -0.13 \\
\hline Mean annual (mm) & 36 & 86 & 62 & 157 & 471 & 121 & 152 \\
\hline
\end{tabular}

\section{Results}

Current climate was perturbed based on climatic changes projected by NARCCAP's RCMs using the SRES A2 scenario. The average differences in annual climatological averages obtained for the future climate (2041-70) and current period (1971-2000) were 16.3\% for $P$ and $2.6^{\circ} \mathrm{C}$ for Ta in WCRB, $6.6 \%$ for $P$ and $2.2^{\circ} \mathrm{C}$ for Ta in MCRB, and $2.3 \%$ for $P$ and $2.4^{\circ} \mathrm{C}$ for Ta in RME. Variability in warming among RCMs was greater in spring when temperature has an important feedback with snowmelt and spring freshet generation (Graversen et al. 2008). The RCM outputs for future show that winter months [December-February (DJF)] warming will reach $2.5^{\circ} \mathrm{C}$ in $\mathrm{MCRB}$ and $\mathrm{RME}$. The winter warming in WCRB will be affected by regional warming at high latitudes and reach $3.5^{\circ} \mathrm{C}$ during $2041-70$.

\section{a. Climate change impacts on snow regimes}

The simulated seasonal distribution of SWE for the perturbed climate in alpine and forest biomes in the three basins was compared to the control period (Fig. 6). Among the three basins, the largest increase by 2041-70
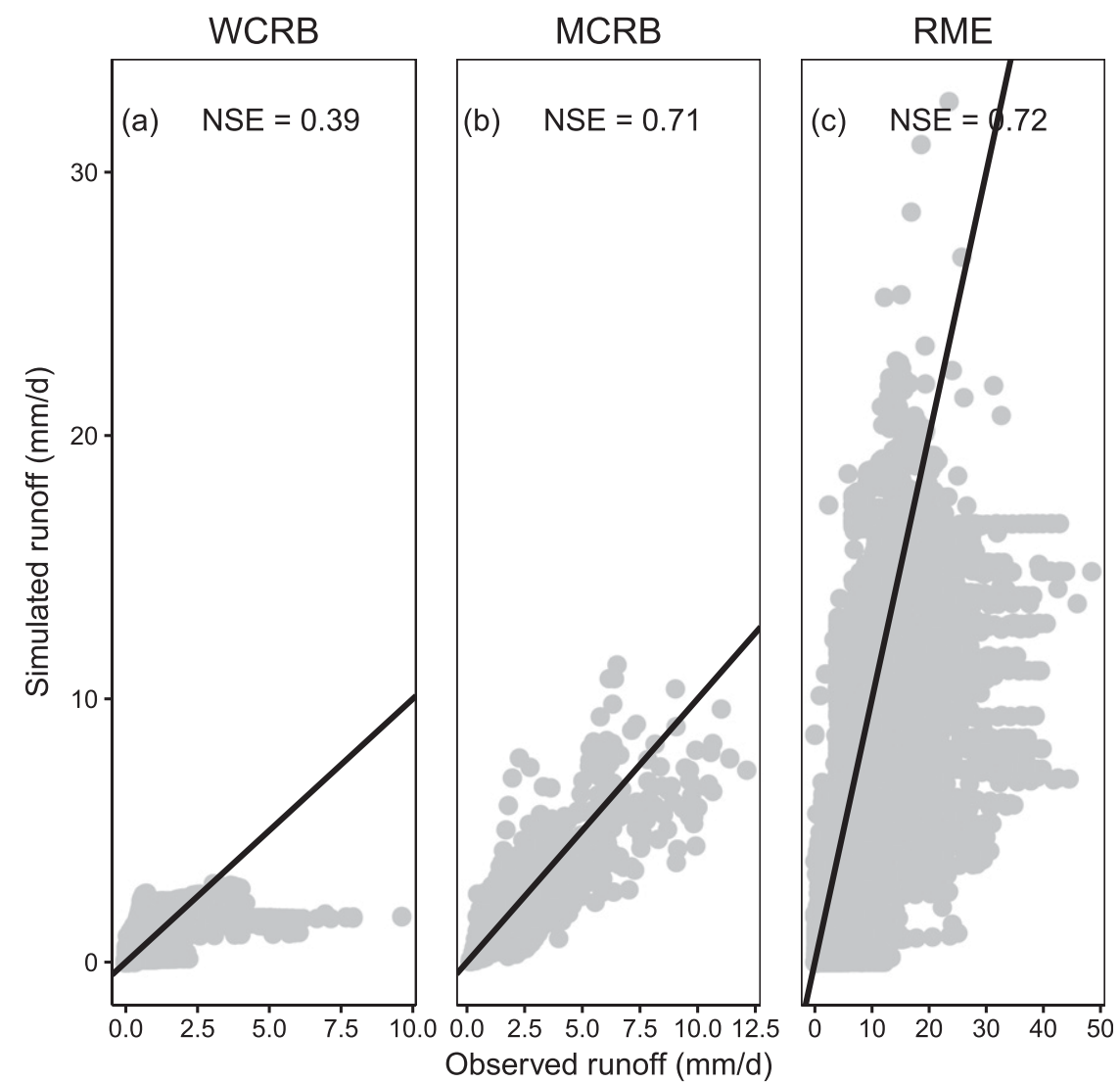

FIG. 5. Performance of the models in capturing daily runoff in (a) WCRB, (b) MCRB, and (c) RME. The MCRB model was developed and assessed by Fang and Pomeroy (2016). The line has a 1:1 slope, which indicates that the models slightly underestimate the high runoffs in WCRB and RME. 
TABLE 4. Model performance statistics for simulating streamflow over the calibration period and entire record period in the three basins across the North American Cordillera. No calibration is applied in the MCRB model.

\begin{tabular}{|c|c|c|c|c|c|c|}
\hline \multirow[b]{2}{*}{ Criteria } & \multicolumn{3}{|c|}{ Calibration } & \multicolumn{3}{|c|}{ Record period } \\
\hline & WCRB & MCRB & RME & WCRB & MCRB & RME \\
\hline NSE (unitless) & 0.64 & - & 0.73 & 0.40 & 0.71 & 0.72 \\
\hline Correlation (unitless) & 0.80 & - & 0.88 & 0.70 & 0.84 & 0.87 \\
\hline $\operatorname{RMSE}\left(\mathrm{m}^{3} \mathrm{~s}^{-1}\right)$ & 0.60 & - & 0.008 & 0.75 & 0.13 & 0.008 \\
\hline $\operatorname{MAE}\left(\mathrm{m}^{3} \mathrm{~s}^{-1}\right)$ & 0.31 & - & 0.003 & 0.37 & 0.09 & 0.003 \\
\hline NMBE (unitless) & -0.02 & - & 0.22 & -0.14 & 0.03 & 0.28 \\
\hline Mean annual discharge $\left(\mathrm{m}^{3} \mathrm{~s}^{-1}\right)$ & 0.76 & - & 0.009 & 0.73 & 0.25 & 0.008 \\
\hline
\end{tabular}

in warming and precipitation is for WCRB. In WCRB, the impacts of increased warming are partly offset by increased precipitation (Figs. 6a,b). Under climate changes, the mean annual peak SWE decreased the most in the forest biome in RME with a decline from 410 to $217 \mathrm{~mm}$. In general, peak SWE in forests across the basins decreased between $11 \%$ and $57 \%$ with the largest decline at lower latitudes (Fig. 6f) and lower elevations (Fig. 6d). The treeline in MCRB had the highest snow accumulation under the current climate due to strong winds that redistribute snow via blowing snow transport from higher alpine elevations into this zone, which shows only a $9 \%$ decline in the simulated peak SWE. The resilient alpine-treeline snowpack in MCRB (Figs. 6c,d) leads to relatively small changes in water balance for this entire basin. The total SWE in this biome is large and lower-elevation biomes have smaller total SWE and smaller SWE losses with climate change.

In contrast to MCRB, all of the biomes in RME show $\sim 47 \%$ decline in peak SWE. The basin-scale SWE decrease is proportionately larger in RME than MCRB and WCRB (Table 5). The heterogeneous climate changes along the North American Cordillera lead to a stronger response of the mean annual peak SWE in the

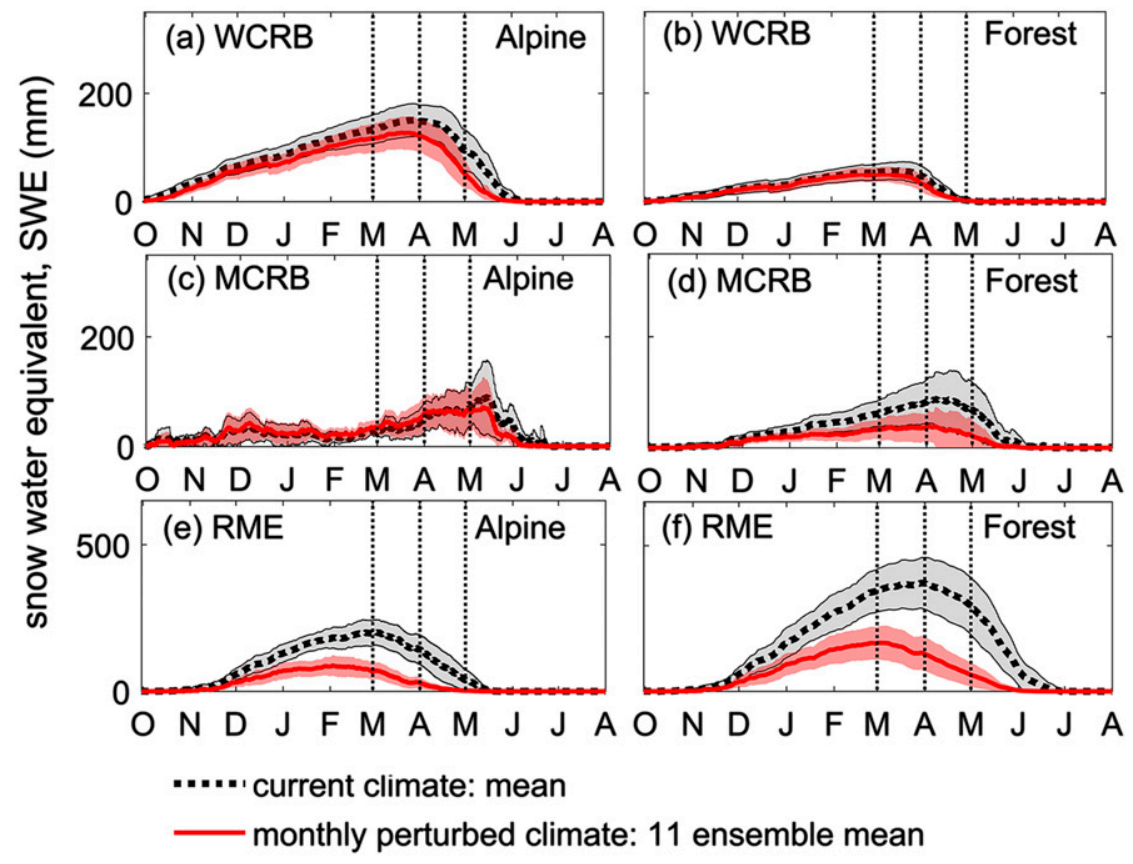

FIG. 6. Snow accumulation and ablation under current and monthly perturbed climates in alpine and forest biomes in (a),(b) WCRB; (c),(d) MCRB; and (e),(f) RME along North American Cordillera. The $y$ axis has different scales for different subplots. The shaded area around the mean shows the interannual variability with $\pm 95 \%$ confidence intervals. The mean response to an ensemble of $11 \mathrm{RCMs}$ is selected to study interannual variability in the perturbed climate. The slope of the snow water equivalent curve during melt season under warmer climate is lower than for the current climate, which suggests a slower melt rate under a warmer climate. This is because the melt period is shifted forward into a lower solar irradiance period. 
TABLE 5. Snow characteristics under current and monthly perturbed climates in the three basins along the western North American Cordillera. Bold values denote significant changes with $p$ values less than 0.05 based on the Mann-Whitney $U$ test. The simulated distributions with $n=18$ years for WCRB, 9 years for MCRB, and 25 years in RME over the control (Base) period for each hydrological variable are compared with the simulated future distributions obtained from $11 \mathrm{RCM}-\mathrm{GCMs}(11 \times n$ values $)$. Changes, which are relative to current climate, are given in parentheses. The negative values represent advances in future timing while the positive values represent delays.

\begin{tabular}{|c|c|c|c|c|}
\hline \multirow[b]{2}{*}{ Variable } & \multirow[b]{2}{*}{ Base } & \multicolumn{3}{|c|}{ Monthly perturbed climate } \\
\hline & & $5 \%$ & Mean & $95 \%$ \\
\hline \multicolumn{5}{|c|}{ Wolf Creek Research basin (WCRB) } \\
\hline Peak SWE (mm) & 133 & $73(-45 \%)$ & $118(-11 \%)$ & $153(15 \%)$ \\
\hline Snow initiation (date) & 5 Oct & 31 Sep ( -5 days) & 7 Oct (2 days) & 16 Nov (42 days) \\
\hline Peak SWE timing (date) & 4 Apr & $20 \mathrm{Feb}$ ( -43 days $)$ & 13 Mar (-22 days) & 27 Mar ( -8 days $)$ \\
\hline Snow-free (date) & 7 Jun & 1 May (-37 days) & 23 May ( -15 days) & 5 Jun ( -2 days $)$ \\
\hline Season length (day) & 224 & 160 ( -64 days $)$ & 207 ( -17 days) & 242 (18 days) \\
\hline \multicolumn{5}{|c|}{ Marmot Creek Research basin (MCRB) } \\
\hline Peak SWE (mm) & 183 & $102(-45 \%)$ & $141(-23 \%)$ & $170(-7 \%)$ \\
\hline Snow initiation (date) & 9 Oct & 4 Oct ( -5 days $)$ & 24 Oct (15 days) & 1 Dec (53 days) \\
\hline Peak SWE timing (date) & 29 Apr & $26 \operatorname{Mar}(-35$ days $)$ & 18 Apr ( -10 days $)$ & 4 May (6 days) \\
\hline Snow-free (date) & $21 \mathrm{Jul}$ & 14 Jun ( -37 days) & 8 Jul (-13 days) & $22 \mathrm{Jul}$ (1 day) \\
\hline Season length (day) & 283 & 204 (-79 days) & 255 ( -28 days) & 277 ( -6 days) \\
\hline \multicolumn{5}{|c|}{ Reynolds Mountain East (RME) } \\
\hline Peak SWE (mm) & 368 & $105(-71 \%)$ & $196(-47 \%)$ & $277(-25 \%)$ \\
\hline Snow initiation (date) & 4 Nov & 20 Oct ( -15 days $)$ & 19 Nov (15 days) & 26 Dec (50 days) \\
\hline Peak SWE timing (date) & $10 \mathrm{Mar}$ & 10 Jan ( -59 days) & 6 Feb (-32 days) & $25 \mathrm{Feb}$ ( -13 days) \\
\hline Snow-free (date) & 3 Jun & 2 Apr (-62 days) & 1 May ( -33 days) & 22 May (-14 days) \\
\hline Season length (day) & 211 & 113 ( -98 days) & 163 ( -48 days $)$ & 197 ( -14 days $)$ \\
\hline
\end{tabular}

southern basin and a smaller response in WCRB. Timing of peak SWE was strongly affected by climate changes. Peak SWE occurred 10-32 days earlier and the snow-cover season ended 13-33 days earlier in all three basins (Table 5), suggesting slower snowmelt due to an earlier melt period shifted into periods of lower insolation.

Peak SWE is hydrologically important as it controls the timing and volume of spring runoff freshet that dominates these three basins. Figures 7-9 show that uncertainty in peak SWE due to uncertainty in climate models is high where peak SWE is high and low where peak SWE is low under climate changes. Figure 7 illustrates that the change in annual peak SWE in the alpine, shrub tundra, and forest biomes in WCRB under modeled current and perturbed climates is always less than $40 \mathrm{~mm}$. The interannual variability of peak SWE under the current climate is high in the alpine and shrub tundra biomes and relatively small in the forest. The uncertainty of simulated peak SWE under climate changes is also high in these biomes. With climate change, the mean annual peak SWE decreases in the three biomes in WCRB, with larger decreases at the higher elevations. Even though the RCM ensemble mean suggests a decline in peak SWE across WCRB, some of the ensemble members suggest a slight increase in the peak SWE, especially in the forest biome. In a drier year with a low peak SWE (e.g., 2004), future hydrology simulations suggest a substantial decline in the snowpack. In contrast to WCRB, the maximum snowpack response to climate change in MCRB is a strong decline at forest and in forest clearings at low elevation and a moderate decline in the alpine and treeline biome, except for extreme cases such as in 2013 when the response of the snowpack is a slight increase (Fig. 8). The differences between modeled current and future climate SWE is less than $100 \mathrm{~mm}$, but much greater than in WCRB. Large sublimation losses from

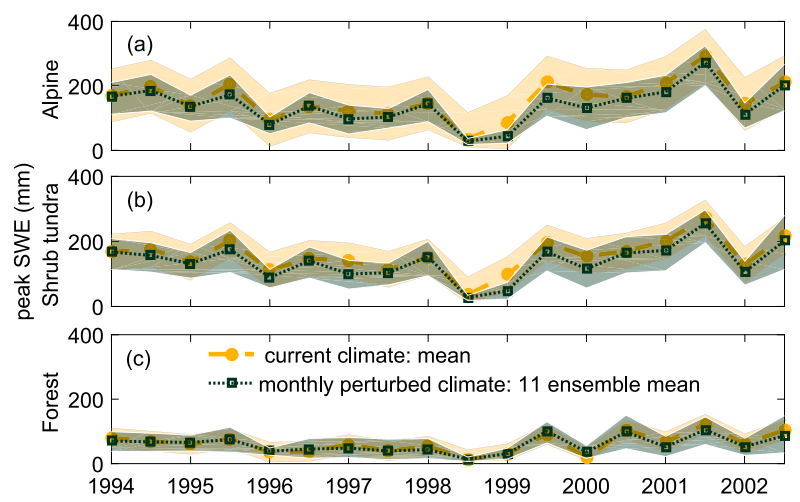

FIG. 7. Simulated peak SWE under current climate in WCRB and responses to monthly perturbed climate. The shaded area around the means shows the simulation uncertainty in the current climate, obtained for each year as the mean and variance of normally distributed simulation error residuals, and ensemble uncertainty due to uncertainty in the climate models in perturbed climate, obtained from a two-parameter Weibull distribution fitted to the 11 ensemble responses, with $\pm 95 \%$ confidence intervals. 

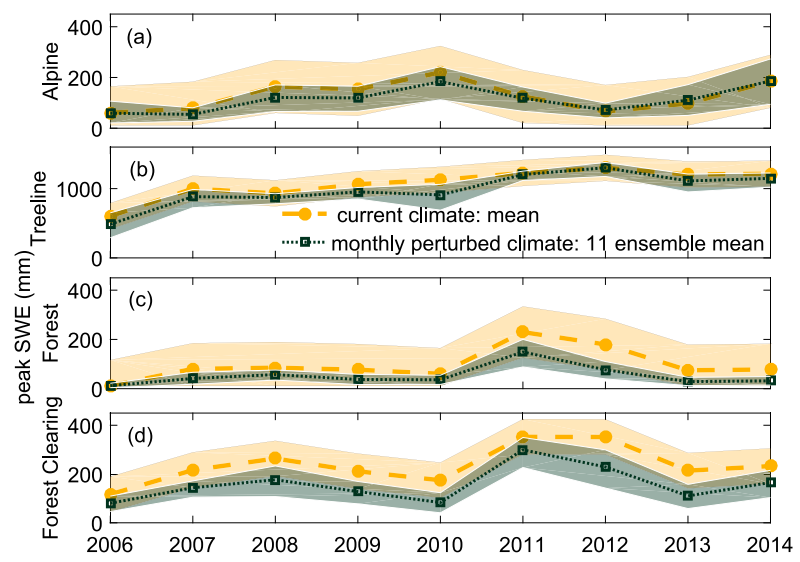

FIG. 8. Simulated peak SWE under current climate in MCRB and responses to monthly perturbed climate. The uncertainty shading is as described in Fig. 7.

intercepted snow at low elevations in MCRB simulated with climate changes are partly responsible for the low snowpacks in the forest. In RME, annual peak SWE is greater than in the other basins, and the difference between modeled current climate and future perturbed climate is greater than in the other basins, up to $450 \mathrm{~mm}$ (Fig. 9). In all three basins, the uncertainty in maximum accumulated snow is low in the forest, along with snow accumulation.

Modeled peak SWE drops more in future climates in warmer biomes-those found at low elevations and latitudes (Figs. 7-9). In colder biomes at higher elevations and latitudes, the declines in peak SWE are much less. In all cases, the uncertainty bands for SWE are large with respect to differences in future climate as not all climate perturbations cause a decrease in peak SWE.

\section{b. Snow processes and evapotranspiration under climate change}

The mean fluxes of water, vapor, and snow in each biome in the three basins were simulated for current and future climates. Mean values for each variable are given in Table 6 and statistically significant changes $(p \leq 0.05)$ are in bold. These headwater basins are currently snowfall-dominated with the ratios of rainfall to total precipitation (rainfall ratio) of $49 \%$ in WCRB, $39 \%$ in MCRB, and 30\% in RME (Table 7). WCRB has a high rainfall ratio due to its summer seasonal precipitation maximum (Fig. 2), while RME has a lower rainfall ratio due to its winter maximum for precipitation occurrence. MCRB has a medium rainfall ratio due to a wide range of elevations and a spring maximum for precipitation occurrence. Under climate perturbation, all three basins shift to increased rainfall proportions of precipitation with a statistically significant increase in rainfall ratios to $59 \%$ for $\mathrm{WCRB}, 53 \%$ for MCRB, and $54 \%$ for RME
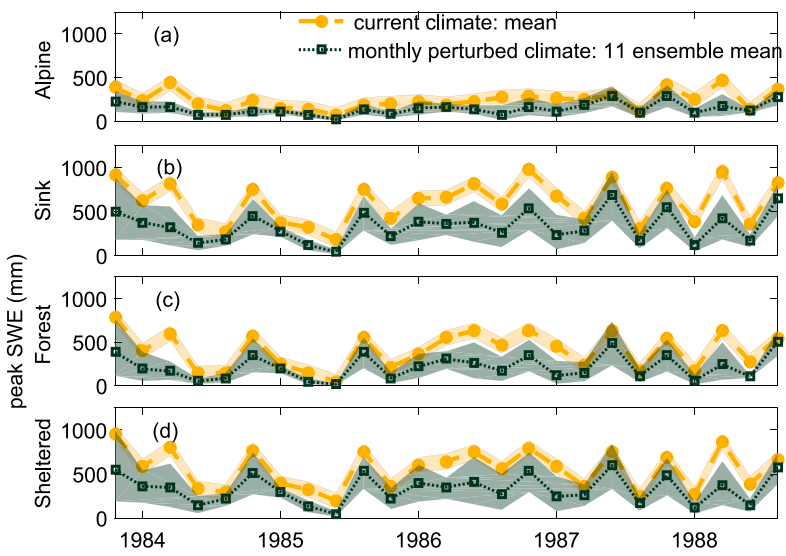

FIG. 9. Simulated peak SWE under current climate in RME and responses to monthly perturbed climate. The uncertainty shading is as described in Fig. 7.

(Table 6), making rainfall the largest precipitation input to all basins. The fractional increases in rainfall ratio were greater in the south than the north even though the initial rainfall ratios were higher in the north. Similar increases in rainfall ratio in different elevation bands in three basins were found with the largest increases at lower elevations.

Blowing snow transport to snowdrifts in the RME sink zone dropped from 79 to $23 \mathrm{~mm}$ with climate change (Table 6). Basin-scale blowing snow transport in RME also decreased with climate change, dropping from 23 to $7 \mathrm{~mm}$. In contrast, changes in snow transport in WCRB were negligible, likely due to its colder winter climate.

Climate changes impacted sublimation from blowing snow, snow intercepted by forest canopies, and the snow surface in different ways. Under the current climate, the magnitude of sublimation losses were considerable in some biomes and the source of sublimation varied with vegetation cover and biome type (Table 6). Changes in sublimation from blowing snow generally reflected changes in snow transport and decreased significantly with climate change in the source (alpine) zone in RME from 51 to $14 \mathrm{~mm}$. The reductions in sublimation from blowing snow in the alpine biome in MCRB and source (alpine) zone in RME were similar and substantial. The alpine biome at WCRB sustained the smallest decrease in sublimation from blowing snow, while the alpine biomes in RME and MCRB had the largest. Sublimation losses from intercepted snow in the southern two basins decreased substantially with climate change from 27 to $17 \mathrm{~mm}$ in MCRB and from 7 to $4 \mathrm{~mm}$ in RME. Intercepted snow sublimation decreases in WCRB, however, were negligible. This reflects its colder winter climate. In general, sublimation from the snow surface is much smaller than the other two sources of sublimation. 
TABLE 6. Mean modeled runoff and water, vapor, and snow fluxes under current and monthly perturbed climates in biomes of the three basins. The statistically significant changes in distributions of the simulated variables between current and perturbed climates are represented by bold values.

\begin{tabular}{|c|c|c|c|c|c|c|c|c|c|c|}
\hline Station & Biome & Climate & Drift in & Rain & Rain ratio & Drift out & Sublimation & ET & Runoff & Runoff ratio \\
\hline \multirow[t]{6}{*}{ WCRB } & \multirow[t]{2}{*}{ Alpine } & Current & 0 & 195 & 0.47 & 3 & 6 & 141 & 263 & 0.64 \\
\hline & & MPC & 0 & 276 & 0.57 & 4 & 6 & 171 & 303 & 0.63 \\
\hline & \multirow[t]{2}{*}{ Shrub tundra } & Current & 1 & 198 & 0.48 & 0 & 0 & 161 & 249 & 0.61 \\
\hline & & MPC & 0 & 279 & 0.59 & 0 & 0 & 192 & 284 & 0.60 \\
\hline & \multirow[t]{2}{*}{ Forest } & Current & 0 & 142 & 0.53 & 0 & 19 & 26 & 222 & 0.83 \\
\hline & & MPC & 0 & 193 & 0.62 & 0 & 19 & 38 & 256 & 0.82 \\
\hline \multirow[t]{8}{*}{ MCRB } & \multirow[t]{2}{*}{ Alpine } & Current & 89 & 349 & 0.29 & 377 & 277 & 138 & 486 & 0.41 \\
\hline & & MPC & 74 & 543 & 0.43 & 318 & 254 & 159 & 604 & 0.48 \\
\hline & \multirow[t]{2}{*}{ Treeline } & Current & 629 & 440 & 0.38 & 6 & 29 & 221 & 1545 & 1.32 \\
\hline & & MPC & 573 & 629 & 0.50 & 3 & 13 & 296 & 1507 & 1.21 \\
\hline & \multirow[t]{2}{*}{ Forest } & Current & 0 & 416 & 0.48 & 0 & 47 & 611 & 211 & 0.24 \\
\hline & & MPC & 0 & 567 & 0.63 & 0 & 29 & 681 & 191 & 0.21 \\
\hline & \multirow[t]{2}{*}{ Forest clearing } & Current & 0 & 413 & 0.47 & 0 & 0 & 436 & 456 & 0.51 \\
\hline & & MPC & 0 & 564 & 0.61 & 0 & 0 & 517 & 407 & 0.44 \\
\hline \multirow[t]{8}{*}{ RME } & \multirow[t]{2}{*}{ Alpine } & Current & 2 & 247 & 0.32 & 42 & 47 & 411 & 281 & 0.36 \\
\hline & & MPC & 1 & 453 & 0.55 & 12 & 13 & 473 & 328 & 0.40 \\
\hline & \multirow[t]{2}{*}{ Forest clearing } & Current & 0 & 259 & 0.27 & 0 & 0 & 423 & 545 & 0.56 \\
\hline & & MPC & 0 & 525 & 0.51 & 0 & 0 & 514 & 514 & 0.50 \\
\hline & \multirow[t]{2}{*}{ Sink } & Current & 79 & 271 & 0.30 & 1 & 1 & 450 & 543 & 0.59 \\
\hline & & MPC & 23 & 526 & 0.54 & 0 & 0 & 542 & 451 & 0.46 \\
\hline & \multirow[t]{2}{*}{ Forest } & Current & 0 & 266 & 0.27 & 0 & 104 & 488 & 376 & 0.39 \\
\hline & & MPC & 0 & 535 & 0.52 & 0 & 59 & 610 & 356 & 0.35 \\
\hline
\end{tabular}

RME showed the greatest magnitude and proportional reduction in surface sublimation with climate change, while MCRB showed the smallest. Total sublimation from all three sources decreased significantly with climate change in the two southern basins; from 32 to $10 \mathrm{~mm}$ in RME and from 119 to $102 \mathrm{~mm}$ in MCRB (Table 6). In contrast, snow sublimation in WCRB remained almost unchanged.

Evapotranspiration (ET) increased with climate change in all biomes within the three study basins (Table 6), the degree of change depending on both warming and the changes in precipitation. The warmer and wetter the climate, the higher the ET rate. This was reflected in RME, where the basin-scale ET increase from 427 to $504 \mathrm{~mm}(74 \mathrm{~mm})$ was the largest. In contrast, MCRB ET increased by a much smaller $55 \mathrm{~mm}$ (from 392 to $447 \mathrm{~mm}$ ), and at WCRB only increased by $27 \mathrm{~mm}$ (from 130 to $157 \mathrm{~mm}$ ). The forest biome in RME showed the greatest increase of any biome to climate changes $(122 \mathrm{~mm})$, likely due to higher annual precipitation, a large shift in rainfall ratio leading to more direct evaporation of intercepted rainfall and limitations in ET from mass balance rather than energy at this lower latitude.

\section{c. Climate change impacts on hydrological regimes}

Annual runoff remained unchanged in RME, but increased $15 \%$ in the alpine and forest of WCRB and $24 \%$ in the alpine of MCRB (Table 6). The impact of increased precipitation on the runoff ratio was muted by compensatory increases in ET losses that were slightly offset by reduced sublimation losses. Except for the alpine in MCRB, where the runoff ratio increased under

TABLE 7. Basin-mean modeled runoff and water, vapor, and snow fluxes under current and monthly perturbed climates in the three basins. The statistically significant changes in distributions of the simulated variables between the current and perturbed climates are represented by bold values.

\begin{tabular}{lclccccrcrc}
\hline \hline Station & Biome & Climate & Drift in & Rain & Rain ratio & Drift out & Sublimation & ET & Runoff & Runoff ratio \\
\hline WCRB & Basin scale & Current & 0 & 186 & 0.49 & 0 & 4 & 130 & 246 & 0.65 \\
& & MPC & 0 & $\mathbf{2 6 1}$ & $\mathbf{0 . 5 9}$ & 0 & 4 & $\mathbf{1 5 7}$ & 283 & 0.64 \\
MCRB & Basin scale & Current & 94 & 395 & 0.39 & 131 & 119 & 392 & 463 & 0.46 \\
& & MPC & 83 & $\mathbf{5 6 5}$ & $\mathbf{0 . 5 3}$ & 110 & $\mathbf{1 0 2}$ & $\mathbf{4 4 7}$ & 486 & 0.46 \\
RME & \multirow{2}{*}{ Basin scale } & Current & 23 & 256 & 0.30 & 24 & 32 & 427 & 387 & 0.46 \\
& & MPC & $\mathbf{7}$ & $\mathbf{4 8 5}$ & $\mathbf{0 . 5 4}$ & $\mathbf{7}$ & $\mathbf{1 0}$ & $\mathbf{5 0 4}$ & 383 & 0.43 \\
\hline
\end{tabular}


climate changes, there was no significant change in the runoff ratio in other locations within the basins or for the basins as a whole (Table 7).

Figure 10 shows the annual hydrographs under current and future climates. Climate change causes high flows to occur earlier and with less intensity in the WCRB hydrograph (Fig. 10a), a large shift in both intensity and timing for RME (Fig. 10c), but not for MCRB (Fig. 10b). Areas under the hydrographs in Fig. 10 represent the annual runoff volumes for current and future climates. Climate change did not cause a significant change in annual runoff volumes in any of the three basins and the uncertainty in the change to future hydrographs is within the range of modeling uncertainty of the current climate.

Changes in the timing of snow accumulation and ablation have great hydrological consequences and can alter runoff timing, rate, and volume in mountain headwater basins. Climate change resulted in the snowfree date advancing by 15,13 , and 33 days in WCRB, MCRB, and RME respectively. As a result, the length of the snow season declined by 17,28 , and 48 days in WCRB, MCRB, and RME, respectively. Simulations using climate change resulted in the snow accumulation initiation date being delayed by 15 days in MCRB and RME (Table 5). The timing of peak SWE, which sets the beginning of the snow ablation period, changed substantially and advanced 22 days (from 4 April to 13 March) in WCRB (Table 6), and 32 days (from 10 March to 6 February) in RME (Table 6). The advance in the snow ablation period was reflected in the timing of high flows, when they were associated with snowmelt (Figs. 10a,c). High flows advanced 8 days in WCRB and 41 days in RME, but remained unchanged in MCRB where they are more often driven by large rainfall events, with or without snowmelt contributions.

\section{Discussion}

In the three basins studied here, cold, well below freezing conditions exist at high elevations in WCRB (Fig. 2a) and MCRB (Fig. 2b), and high precipitation amounts in cold months occur in RME (Fig. 2c). These are the main factors responsible for the relatively small changes in SWE in the alpine elevations. With warmer temperatures and changing precipitation patterns, modeled using the SRES A2 greenhouse gas emission scenario, all three of the currently snow-dominated basins show an increased importance of rainfall in the hydrological cycle especially in spring and winter. These predicted changes are in agreement with findings by Nayak et al. (2010) for the historical period in the low elevations and Nayak (2008) for $\mathrm{a}+2^{\circ} \mathrm{C}$ warming scenario at high

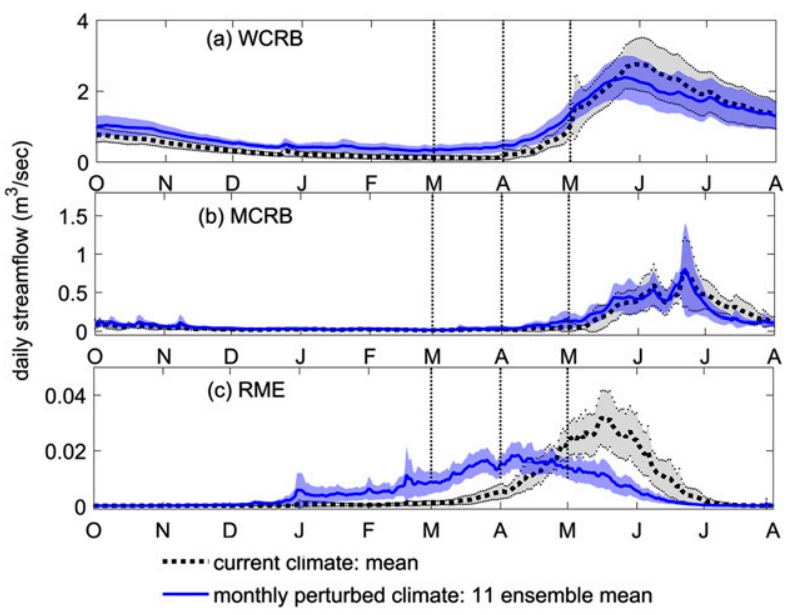

FIG. 10. Differences in the annual hydrograph under current and monthly perturbed climates in the three basins across the North American Cordillera. The onset of freshet occurs earlier in WCRB and RME, and runoff maxima shifts 8 and 41 days, respectively in these two basins. The shaded area around the means shows the interannual variability in current climate and ensemble mean of 11 responses to perturbed climates with $\pm 95 \%$ confidence intervals.

elevations in Reynolds Creek. Precipitation phase is very sensitive to warming at low elevations and basins with winter temperatures warmer than $-5^{\circ} \mathrm{C}$ (Knowles et al. 2006). This implies that under climate change, RME, a high-elevation subbasin within Reynolds Creek which has so far been resistant to the hydrological impacts of climate warming, will be subject to the impacts of changes in precipitation phase. The lower and middle elevations in MCRB, and all elevation bands in RME and WCRB will shift from snowmelt-runoff toward increasing dominance of rainfall-runoff under the SRES A2 scenario climate change-this is similar to what has already happened at low elevations in Reynolds Creek (Nayak et al. 2010). The hydrological sensitivity of mountain basins to a warming climate has been found to depend on the elevation of the basins (Stewart et al. 2004), precipitation phase, and surface humidity (Marks et al. 2013). Snow regime and snowmelt runoff timing in high-elevation basins with winters well below the freezing point have been shown to be less sensitive to warming than low-elevation basins (Stewart et al. 2004).

With the shift toward rainfall from snowfall, the expected increases in precipitation result in more ET than in more runoff. In MCRB and RME, the impact of the snowfall to rainfall shift reduces peak SWE (Table 5) and the increases in precipitation are offset by increases in ET, resulting in no change in annual mean runoff (Table 6). This is consistent with a recent study by Harder et al. (2015) that showed no significant changes in annual runoff, timing of peak, and magnitude of the 
peak runoff in MCRB over 52 years. The runoff ratio also remains unchanged in all three basins under the $\mathrm{A} 2$ climate changes. At WCRB, the snow season period shortens, ET increases, and the rainfall ratio increases (Tables 5,6) which, when combined, results in no change in annual runoff under the climate changes (Fig. 10). This suggests that the snow and runoff regimes in WCRB are relatively resilient to the combination of warming and precipitation increase due to the relatively cold climate and the compensating role of increased precipitation offsetting the hydrological impact of warming (Rasouli et al. 2014). In MCRB, with A2 climate changes, less snow occurs at lower elevations; however, the snow regime at high elevations in MCRB are relatively unaffected (Table 6), due to cold temperatures and the spring to early summer precipitation maximum (Fig. 2b) leaving the runoff regime and annual runoff unchanged (Table 7). When peak precipitation occurs in synchrony with the melt season, then its phase is less important than where it comes earlier as in RME or later as in WCRB.

Leith and Whitfield (1998) and later Barnett et al. (2005) showed that warming in snow-dominated regions results in less winter precipitation falling as snow and an earlier start to spring snowmelt, both leading to temporal shifts in seasonal high snowmelt runoff. In these three mountain basins, an earlier start to the spring freshet occurs with climate change (Fig. 10), this is particularly evident in RME, which has winter temperatures that are currently the nearest to the freezing point. In the two colder basins, the shift is less dramatic. Other studies also show a seasonal shift to earlier spring runoff in RME (Nayak 2008) and in a broader scale in western Canada (Leith and Whitfield 1998; Whitfield and Cannon 2000) and the western United States (Rauscher et al. 2008). Depending on how cold winter temperatures are, the magnitude of spring runoff increased while magnitude of late summer runoff decreased with changing climate in all three basins (Fig. 10). This was also shown by Brubaker and Rango (1996) and Sorg et al. (2012). Winter temperatures in both high-elevation (MCRB) and high-latitude (WCRB) basins remain well below the freezing point despite the expected warming. In general, cold areas that remain cold and do not cross the freezing point in winter do not show a hydrological response to climate changes. In contrast, cool areas where winter temperatures are near $0^{\circ} \mathrm{C}$ (above $-5^{\circ} \mathrm{C}$ in RME; Fig. $2 \mathrm{c}$ ) are very sensitive to warming.

Simulated blowing snow transport and sublimation were reduced in RME and MCRB with the future SRES A2 scenario, likely due to higher air temperatures and less snowfall, which raise the threshold wind speed that must be exceeded for blowing snow transport. They remained unchanged in WCRB (Table 6), likely due to its much colder winter temperatures. MacDonald et al. (2010) estimated sublimation losses in MCRB to be $20 \%-32 \%$ of total annual snowfall. Under the A2 climate changes, simulations show smaller blowing snow losses in RME and MCRB are because of the lower snow accumulation (Rasouli et al. 2015) and the increasing bond strength and cohesion of snow as it warms, which raises the threshold wind speed required to initiate saltation ( $\mathrm{Li}$ and Pomeroy 1997).

Simulations of the A2 climate changes show that losses through ET increased in all of the biomes in the three study basins (Table 6). The degree of increase in ET tracked with both warming and increased precipitation. Reduced sublimation losses from snowpacks and increased precipitation offset the impact of increased ET on annual runoff (Table 7).

Maurer et al. (2007) found that the annual hydrograph shift to earlier spring runoff and lower snowpack at the end of winter in the Sierra Nevada, California, was statistically significant because the hydrological shift was large compared to the GCM uncertainty and the Sierra Nevada is sensitive to warming. This was not the case for all three basins in the present study (Table 7). The uncertainty in projected changes in the magnitude of peak SWE was greater than shifts due to climate change at all elevations in WCRB and at high elevations in MCRB (Figs. 7a, 8a). At lower elevations in MCRB (Figs. 8c,d), or with low amounts of SWE (RME, Fig. 9a) projected changes are statistically significant. At higher elevations and where winter peak SWE is large, no difference due to climate change can be detected (Figs. 7a, 8a, 9a). The hydrological uncertainty due to variation between the climate models (Figs. 7-9) was greater than the hydrological changes due to climate change in all three basins. This finding makes it clear that the uncertainties in estimates of the forcing meteorological variables needed for simulating runoff (Hay et al. 2000) and snow processes (MacDonald et al. 2016) in mountainous basins need to be reduced to obtain adequate projections for future mountain snow hydrology.

These three basins may not be representative of all mountain basins across the North American Cordillera; however, they are illustrative of the complexity of hydrological changes that could occur in future. The simulations presented here are for only one future scenario (A2) and uncertainty due to selection of alternate future scenarios or representative concentration pathways was not incorporated in this paper. Despite the importance of detailed observations to this study, the records are short and streamflow measurements are not continuous in either WCRB or MCRB; longer records would be 
desirable. There is also a large difference in basin size, which may cause some uncertainties in interpreting comparisons of streamflow simulations. For consistency, runoff depths (discharge per unit of the drainage area) were used instead of discharges.

The simulations presented for climate change used perturbations of only temperature and precipitation, and did not include other variables or changes in weather patterns. The simulations assumed that in the future the sequencing of weather will be the same as in the observed period and that there will be no structural changes in weather pattern, or changes in precipitation and precipitation processes that might accompany changes in synoptic patterns in the future. Changes in duration and intermittency of precipitation patterns are expected in future climates. Despite these limits, the results of the $\mathrm{A} 2$ climate perturbation driven simulations demonstrate the following:

1) The partitioning of rainfall and snowfall is affected by climate change, and the impact of shifts in rainfall ratio was detected in elevations of each of the mountain basins.

2) Cold areas that remain cold and do not cross above $0^{\circ} \mathrm{C}$ do not show much response to the climate perturbation forcings.

3) There are strong responses in cool zones where temperatures are near $0^{\circ} \mathrm{C}$ and can easily rise above $0^{\circ} \mathrm{C}$ with climate change.

4) The importance of blowing snow redistribution and sublimation is reduced with warming.

5) The resulting hydrological uncertainty associated with the climate ensemble inputs is greater that the hydrological change that needs to be detected.

6) Streamflow volumes did not change in the simulated future climates; changes in the hydrograph related to the timing of snowmelt did occur, but there was no change in total water supply found for these mountain basins.

\section{Conclusions}

The change in mountain snow and runoff regimes in three headwater basins in the North American Cordillera were investigated under simulated warmer and wetter conditions in an uncertainty framework. Future projections from 11 of the NARCAAP RCM-GCM for the SRES A2 greenhouse gas emission scenario for the period 2041-70 were used to perturb records of observations of temperature and precipitation in the basins. Monthly changes ranged between increases from $2.2^{\circ}$ to $2.6^{\circ} \mathrm{C}$ in temperature and increases from $2.3 \%$ to $16.3 \%$ in precipitation. The perturbed observations were then used as forcings in physically based hydrological models developed for the present climate; the hydrology forced with perturbed observations was compared to the present and the differences indicate how these mountain basins responded to a future climate. The results showed increased rainfall importance and reduced snow dominance under monthly perturbed climate for low elevations in MCRB, and for all elevation bands in RME and WCRB; the snow regime changed the least in the northern basin with cold winters and the most in the southern basin where winter temperatures are nearer to the freezing point. The response of snow regime in MCRB to climate changes became weaker with increasing elevation. Snow losses through sublimation and snow transport by blowing snow was reduced in MCRB and RME with climate changes. In contrast, losses through ET increased in all of the biomes within the three study basins, the degree of change depending on both warming and the changes in precipitation. The impact on annual runoff of precipitation increases and the shift toward rainfall rather than snowfall were moderated by increased ET.

The results demonstrate that the hydrological changes in all three basins and the snow regime changes in WCRB and at high elevations in MCRB were small compared to the uncertainty in climate change due to atmospheric models. This limits the ability to detect hydrological change impacts of future climate change in mountain basins. To obtain projections for future mountain snow hydrology with adequate confidence, the uncertainty of future projections in mountainous areas needs to be reduced. The changes in magnitude of peak SWE and timing of snow initiation and peak SWE, snow free date, and length of snow-cover season were statistically significant in MCRB and RME. Despite many significant changes in precipitation, peak SWE, and alpine runoff within their subbasins, basin scale annual runoff and runoff ratio remained unchanged in all three basins. In RME, the annual hydrograph regime shifted under climate changes from summer toward winter and early spring runoff; however, this is not the case in WCRB or MCRB. The results of this study can inform water resources stakeholders regarding the vulnerability of alpine headwaters to first-order climate change impacts. Further investigation is needed to consider the impact of other possible temperature and precipitation changes, and in other mountainous regions around the world.

Acknowledgments. Danny Marks of USDA provided the data for Reynolds Mountain East and the late Rick Janowicz of Yukon Environment provided the Wolf Creek data; we appreciate their efforts and commitment to the long-term collection of these high-quality records. 
The research was funded by the Natural Sciences and Engineering Research Council's Discovery Grants, Changing Cold Regions Network and Alexander Graham Bell Canada Graduate Scholarship-Doctoral Program. Xing Fang provided guidance on the development of CRHM models and provided the Marmot Creek model. The comments and suggestions of the Editor and two reviewers helped to improve this paper.

\section{REFERENCES}

Barnett, T. P., J. C. Adam, and D. P. Lettenmaier, 2005: Potential impacts of a warming climate on water availability in snowdominated regions. Nature, 438, 303-309, https://doi.org/ 10.1038/nature04141.

Barry, R. G., 1992: Mountain climatology and past and potential future climatic changes in mountain regions: A review. $M t$ Res. Dev., 12, 71-86, https://doi.org/10.2307/3673749.

Bennett, K. E., A. T. Werner, and M. Schnorbus, 2012: Uncertainties in hydrologic and climate change impact analyses in headwater basins of British Columbia. J. Climate, 25, 57115730, https://doi.org/10.1175/JCLI-D-11-00417.1.

Blöschl, G., and Coauthors, 2007: At what scales do climate variability and land cover change impact on flooding and low flows? Hydrol. Processes, 21, 1241-1247, https://doi.org/ 10.1002/hyp.6669.

Boé, J., and F. Habets, 2014: Multi-decadal river flow variations in France. Hydrol. Earth Syst. Sci., 18, 691-708, https://doi.org/ 10.5194/hess-18-691-2014

Brubaker, K. L., and A. Rango, 1996: Response of snowmelt hydrology to climate change. Water Air Soil Pollut., 90, 335-343, https://doi.org/10.1007/BF00619293.

Cannon, A. J., 2008: Probabilistic multisite precipitation downscaling by an expanded Bernoulli gamma density network. J. Hydrometeor., 9, 1284-1300, https://doi.org/10.1175/2008JHM960.1.

Carey, S. K., and M.-K. Woo, 2001: Slope runoff processes and flow generation in a subarctic, subalpine catchment. J. Hydrol., 253, 110-129, https://doi.org/10.1016/S0022-1694(01)00478-4.

_, W. L. Quinton, and N. T. Goeller, 2007: Field and laboratory estimates of pore size properties and hydraulic characteristics for subarctic organic soils. Hydrol. Processes, 21, 2560-2571, https://doi.org/10.1002/hyp.6795.

DeBeer, C. M., and J. W. Pomeroy, 2010: Simulation of the snowmelt runoff contributing area in a small alpine basin. Hydrol. Earth Syst. Sci., 14, 1205-1219, https://doi.org/10.5194/ hess-14-1205-2010.

Deser, C., A. Phillips, V. Bourdette, and H. Teng, 2012: Uncertainty in climate change projections: the role of internal variability. Climate Dyn., 38, 527-546, https://doi.org/10.1007/ s00382-010-0977-x.

Dornes, P. F., J. W. Pomeroy, A. Pietroniro, S. K. Carey, and W. L. Quinton, 2008: Influence of landscape aggregation in modelling snow-cover ablation and snowmelt runoff in a sub-arctic mountainous environment. Hydrol. Sci. J., 53, 725-740, https:// doi.org/10.1623/hysj.53.4.725.

Ellis, C. R., J. W. Pomeroy, T. Brown, and J. P. MacDonald, 2010: Simulation of snow accumulation and melt in needleleaf forest environments. Hydrol. Earth Syst. Sci., 14, 925-940, https:// doi.org/10.5194/hess-14-925-2010.

— — — R. Essery, and T. Link, 2011: Effects of needleleaf forest cover on radiation and snowmelt dynamics in the Canadian
Rocky Mountains. Can. J. For. Res., 41, 608-620, https://doi.org/ 10.1139/X10-227.

Elsner, M. M., S. Gangopadhyay, T. Pruitt, L. D. Brekke, N. Mizukami, and M. P. Clark, 2014: How does the choice of distributed meteorological data affect hydrologic model calibration and streamflow simulations? J. Hydrometeor., 15, 1384-1403, https://doi.org/10.1175/JHM-D-13-083.1.

Essery, R., L. Li, and J. W. Pomeroy, 1999: Blowing snow fluxes over complex terrain. Hydrol. Processes, 13, 2423-2438, https:// doi.org/10.1002/(SICI)1099-1085(199910)13:14/15<2423::AIDHYP853>3.0.CO;2-U.

Fang, X., and J. W. Pomeroy, 2016: Impact of antecedent conditions on simulations of a flood in a mountain headwater basin. Hydrol. Processes, 30, 2754-2772, https://doi.org/10.1002/ hyp.10910.

, — , C. Ellis, M. MacDonald, C. DeBeer, and T. Brown, 2013: Multi-variable evaluation of hydrological model predictions for a headwater basin in the Canadian Rocky Mountains. Hydrol. Earth Syst. Sci., 17, 1635-1659, https:// doi.org/10.5194/hess-17-1635-2013.

, — C C. M. DeBeer, P. Harder, and E. Siemens, 2019: Hydrometeorological data from Marmot Creek Research Basin, Canadian Rockies. Earth Syst. Sci. Data, 11, 455-471, https:// doi.org/10.5194/essd-11-455-2019.

Flerchinger, G. N., M. L. Reba, and D. Marks, 2012: Measurement of surface energy fluxes from two rangeland sites and comparison with a multilayer canopy model. J. Hydrometeor., 13, 1038-1051, https://doi.org/10.1175/JHM-D-11-093.1.

Fowler, H., S. Blenkinsop, and C. Tebaldi, 2007: Linking climate change modelling to impacts studies: Recent advances in downscaling techniques for hydrological modelling. Int. J. Climatol., 27, 1547-1578, https://doi.org/10.1002/joc.1556.

Francis, S., S. Smith, and R. Janowicz, 1999: Data integration and ecological zonation of Wolf Creek watershed. Wolf Creek Research Basin: Hydrology, Ecology, Environment, J. W. Pomeroy and R. J. Granger, Environment Canada, 93-100.

Gaitan, C. F., W. W. Hsieh, and A. J. Cannon, 2014: Comparison of statistically downscaled precipitation in terms of future climate indices and daily variability for southern Ontario and Quebec, Canada. Climate Dyn., 43, 3201-3217, https://doi.org/ 10.1007/s00382-014-2098-4.

Goodison, B., P. Louie, and D. Yang, 1998: WMO solid precipitation intercomparison. Instruments and Observing Methods Rep. 67, WMO/TD-872, 212 pp., https://www.wmo.int/ pages/prog/www/IMOP/publications/IOM-67-solid-precip/ WMOtd872.pdf.

Graversen, R. G., T. Mauritsen, M. Tjernström, E. Källén, and G. Svensson, 2008: Vertical structure of recent Arctic warming. Nature, 451, 53-56, https://doi.org/10.1038/nature06502.

Guilyardi, E., and Coauthors, 2004: Representing El Niño in coupled ocean-atmosphere GCMs: the dominant role of the atmospheric component. J. Climate, 17, 4623-4629, https:// doi.org/10.1175/JCLI-3260.1.

Gutmann, E., T. Pruitt, M. P. Clark, L. Brekke, J. R. Arnold, D. A. Raff, and R. M. Rasmussen, 2014: An intercomparison of statistical downscaling methods used for water resource assessments in the United States. Water Resour. Res., 50, 71677186, https://doi.org/10.1002/2014WR015559.

, I. Barstad, M. Clark, J. Arnold, and R. Rasmussen, 2016: The Intermediate Complexity Atmospheric Research Model (ICAR). J. Hydrometeor., 17, 957-973, https://doi.org/10.1175/ JHM-D-15-0155.1. 
Hamlet, A. F., and D. P. Lettenmaier, 1999: Effects of climate change on hydrology and water resources in the Columbia River Basin. J. Amer. Water Resour. Assoc., 35, 1597-1623, https://doi.org/10.1111/j.1752-1688.1999.tb04240.x.

Harder, P., J. W. Pomeroy, and C. J. Westbrook, 2015: Hydrological resilience of a Canadian Rockies headwaters basin subject to changing climate, extreme weather, and forest management. Hydrol. Processes, 29, 3905-3924, https://doi.org/ 10.1002/hyp.10596.

Hay, L. E., R. L. Wilby, and G. H. Leavesley, 2000: A comparison of delta change and downscaled GCM scenarios for three mountainous basins in the United States. J. Amer. Water Resour. Assoc., 36, 387-397, https://doi.org/10.1111/j.17521688.2000.tb04276.x.

Hidalgo, H. G., and J. A. Dracup, 2003: ENSO and PDO effects on hydroclimatic variations of the Upper Colorado River Basin. J. Hydrometeor., 4, 5-23, https://doi.org/10.1175/15257541(2003)004<0005:EAPEOH >2.0.CO;2.

Hijmans, R. J., S. E. Cameron, J. L. Parra, P. G. Jones, and A. Jarvis, 2005: Very high resolution interpolated climate surfaces for global land areas. Int. J. Climatol., 25, 1965-1978, https://doi.org/10.1002/joc.1276.

Hrachowitz, M., and M. Weiler, 2011: Uncertainty of precipitation estimates caused by sparse gauging networks in a small, mountainous watershed. J. Hydrol. Eng., 16, 460-47, https:// doi.org/10.1061/(ASCE)HE.1943-5584.0000331.

Hsieh, W. W., 2009: Machine Learning Methods in the Environmental Sciences: Neural Networks and Kernels. Cambridge University Press, $349 \mathrm{pp}$.

Kawase, H., T. Yoshikane, M. Hara, F. Kimura, T. Yasunari, B. Ailikun, H. Ueda, and T. Inoue, 2009: Intermodel variability of future changes in the baiu rainband estimated by the pseudo global warming downscaling method.J. Geophys. Res., 114, D24110, https://doi.org/10.1029/2009JD011803.

Kirby, C., and R. Ogilvie, 1969: The forests of Marmot Creek watershed research basin. Canadian Forestry Service Publ. $1259,37 \mathrm{pp}$.

Klemeš, V., 1990: The modelling of mountain hydrology: The ultimate challenge. IAHS Publ., 190, 29-43.

Knowles, N., and D. R. Cayan, 2004: Elevational dependence of projected hydrologic changes in the San Francisco estuary and watershed. Climatic Change, 62, 319-336, https://doi.org/ 10.1023/B:CLIM.0000013696.14308.b9.

—, M. D. Dettinger, and D. R. Cayan, 2006: Trends in snowfall versus rainfall in the western United States. J. Climate, 19, 4545-4559, https://doi.org/10.1175/JCLI3850.1.

Kumar, M., D. Marks, J. Dozier, M. Reba, and A. Winstral, 2013: Evaluation of distributed hydrologic impacts of temperatureindex and energy-based snow models. Adv. Water Resour., 56, 77-89, https://doi.org/10.1016/j.advwatres.2013.03.006.

Leith, R. M., and P. H. Whitfield, 1998: Evidence of climate change effects on the hydrology of streams in south-central BC. Can. Water Resour. J., 23, 219-230, https://doi.org/10.4296/ cwrj2303219.

Leung, L. R., and S. J. Ghan, 1999: Pacific Northwest climate sensitivity simulated by a regional climate model driven by a GCM. Part II: $2 \times \mathrm{CO}_{2}$ simulations. J. Climate, 12, 2031-2053, https://doi.org/10.1175/1520-0442(1999)012<2031:PNCSSB > 2.0.CO;2.

Lewkowicz, A. G., and M. Ednie, 2004: Probability mapping of mountain permafrost using the BTS method, Wolf Creek, Yukon Territory, Canada. Permafr. Periglac. Process., 15, 67-80, https://doi.org/10.1002/ppp.480.
Li, L., and J. W. Pomeroy, 1997: Probability of occurrence of blowing snow. J. Geophys. Res., 102, 21 955-21 964, https:// doi.org/10.1029/97JD01522.

Link, T. E., G. N. Flerchinger, M. Unsworth, and D. Marks, 2004: Simulation of water and energy fluxes in an old-growth seasonal temperate rain forest using the simultaneous heat and water (SHAW) model. J. Hydrometeor., 5, 443-457, https:// doi.org/10.1175/1525-7541(2004)005<0443:SOWAEF $>2.0 . C O ; 2$.

López-Moreno, J. I., and Coauthors, 2014: The effect of slope aspect on the response of snowpack to climate warming in the Pyrenees. Theor. Appl. Climatol., 117, 207-219, https:// doi.org/10.1007/s00704-013-0991-0.

MacDonald, J. P., 2010: Unloading of intercepted snow in conifer forests. M.S. thesis, Dept. of Geography, University of Saskatchewan, 93 pp., http://hdl.handle.net/10388/etd-09302010145706.

MacDonald, M. K., J. W. Pomeroy, and A. Pietroniro, 2009: Parameterizing redistribution and sublimation of blowing snow for hydrological models: Tests in a mountainous subarctic catchment. Hydrol. Processes, 23, 2570-2583, https://doi.org/ 10.1002/hyp.7356.

,-- , and -2010 : On the importance of sublimation to an alpine snow mass balance in the Canadian Rocky Mountains. Hydrol. Earth Syst. Sci., 14, 1401-1415, https://doi.org/10.5194/ hess-14-1401-2010.

- B. J. Davison, M. A. Mekonnen, and A. Pietroniro, 2016: Comparison of land surface scheme simulations with field observations versus atmospheric model output as forcing. Hydrol. Sci. J., 61, 2860-2871, https://doi.org/10.1080/ 02626667.2016 .1177185 .

Mann, H. B., and D. R. Whitney, 1947: On a test of whether one of two random variables is stochastically larger than the other. Ann. Math. Stat., 18, 50-60, https://doi.org/10.1214/aoms/ 1177730491.

Mann, M. E., U. Lall, and B. Saltzman, 1995: Decadal-to-centennialscale climate variability: Insights into the rise and fall of the Great Salt Lake. Geophys. Res. Lett., 22, 937-940, https:// doi.org/10.1029/95GL00704

Maples, A., M. McHugh, and E. Brown, 2014: Downscaled climate models in complex topographical regions: Relevancy for water utility planning. J. Water Climate Change, 5, 540-555, https:// doi.org/10.2166/wcc.2014.036.

Maraun, D., and Coauthors, 2010: Precipitation downscaling under climate change: Recent developments to bridge the gap between dynamical models and the end user. Rev. Geophys., $\mathbf{4 8}$ RG3003, https://doi.org/10.1029/2009RG000314.

Marks, D., and J. Dozier, 1992: Climate and energy exchange at the snow surface in the alpine region of the Sierra Nevada: 2. Snow cover energy balance. Water Resour. Res., 28, 3043-3054, https://doi.org/10.1029/92WR01483.

_ J. Kimball, D. Tingey, and T. Link, 1998: The sensitivity of snowmelt processes to climate conditions and forest cover during rain-on-snow: A case study of the 1996 Pacific Northwest flood. Hydrol. Processes, 12, 1569-1587, https://doi.org/ 10.1002/(SICI)1099-1085(199808/09)12:10/11<1569::AIDHYP682>3.0.CO;2-L.

—, A. Winstral, M. Reba, J. Pomeroy, and M. Kumar, 2013: An evaluation of methods for determining during-storm precipitation phase and the rain/snow transition elevation at the surface in a mountain basin. Adv. Water Resour., 55, 98-110, https://doi.org/10.1016/j.advwatres.2012.11.012.

Maurer, E. P., I. T. Stewart, C. Bonfils, P. B. Duffy, and D. Cayan, 2007: Detection, attribution, and sensitivity of trends toward 
earlier streamflow in the Sierra Nevada. J. Geophys. Res., 112 D11118, https://doi.org/10.1029/2006JD008088.

McCartney, S. E., S. K. Carey, and J. W. Pomeroy, 2006: Intra-basin variability of snowmelt water balance calculations in a subarctic catchment. Hydrol. Processes, 20, 1001-1016, https:// doi.org/10.1002/hyp.6125.

Mearns, L., W. Gutowski, R. Jones, L. Leung, S. McGinnis, A. Nunes, and Y. Qian, 2007: The North American regional climate change assessment program dataset. National Center for Atmospheric Research Earth System Grid Data Portal, accessed 10 September 2013, https://doi.org/ 10.5065/D6RN35ST.

Meybeck, M., P. Green, and C. Vörösmarty, 2001: A new typology for mountains and other relief classes: An application to global continental water resources and population distribution. Mt Res. Dev., 21, 34-45, https://doi.org/10.1659/0276-4741(2001) 021[0034:ANTFMA]2.0.CO;2.

Mote, P. W., A. F. Hamlet, M. P. Clark, and D. P. Lettenmaier, 2005: Declining mountain snowpack in western North America. Bull. Amer. Meteor. Soc., 86, 39-49, https://doi.org/ 10.1175/BAMS-86-1-39.

Nayak, A., 2008: The effect of climate change on the hydrology of a mountainous catchment in the western United States: A case study at Reynolds Creek, Idaho. Utah State University, pp. 194.

, D. Marks, D. G. Chandler, and M. Seyfried, 2010: Long-term snow, climate, and streamflow trends at the Reynolds Creek Experimental Watershed, Owyhee Mountains, Idaho, United States. Water Resour. Res., 46, W06519, https://doi.org/10.1029/ 2008WR007525.

Naz, B. S., C. D. Frans, G. K. C. Clarke, P. Burns, and D. P. Lettenmaier, 2014: Modeling the effect of glacier recession on streamflow response using a coupled glacio-hydrological model. Hydrol. Earth Syst. Sci., 18, 787-802, https://doi.org/ 10.5194/hess-18-787-2014.

- S. C. Kao, M. Ashfaq, D. Rastogi, R. Mei, and L. C. Bowling, 2016: Regional hydrologic response to climate change in the conterminous United States using high-resolution hydroclimate simulations. Global Planet. Change, 143, 100-117, https://doi.org/10.1016/j.gloplacha.2016.06.003.

Nijssen, B., G. M. O'donnell, A. F. Hamlet, and D. P. Lettenmaier, 2001: Hydrologic sensitivity of global rivers to climate change. Climatic Change, 50, 143-175, https://doi.org/10.1023/A: 1010616428763.

Ouachani, R., Z. K. Bargaoui, and T. Ouarda, 2013: Power of teleconnection patterns on precipitation and streamflow variability of upper Medjerda Basin. Int. J. Climatol., 33, 58-76, https://doi.org/10.1002/joc.3407.

Pomeroy, J. W., and L. Li, 2000: Prairie and Arctic areal snow cover mass balance using a blowing snow model. J. Geophys. Res., 105, 26 619-26 634, https://doi.org/10.1029/2000JD900149.

_ D. M. Gray, and P. G. Landine, 1993: The prairie blowing snow model: characteristics, validation, operation. J. Hydrol. 144, 165-192, https://doi.org/10.1016/0022-1694(93)90171-5.

,,-- K. R. Shook, B. Toth, R. L. H. Essery, A. Pietroniro, and N. R. Hedstrom, 1998: An evaluation of snow accumulation and ablation processes for land surface modelling. Hydrol. Processes, 12, 2339-2367, https://doi.org/10.1002/ (SICI)1099-1085(199812)12:15<2339::AID-HYP800>3.0.CO;2-L.

- N. Hedstrom, and J. Parviainen, 1999: The snow mass balance of Wolf Creek, Yukon: effects of snow sublimation and redistribution. Wolf Creek Research Basin: Hydrology, Ecology, Environment, J. W. Pomeroy and R. J. Granger, Environment Canada, 15-30.
—, B. Toth, R. J. Granger, N. R. Hedstrom, and R. L. H. Essery, 2003: Variation in surface energetics during snowmelt in a subarctic mountain catchment. J. Hydrometeor., 4, 702-719, https://doi.org/10.1175/1525-7541(2003)004<0702:VISEDS > 2.0.CO;2.

— Processes, 20, 923-941, https://doi.org/10.1002/hyp.6124.

, D. M. Gray, T. Brown, N. Hedstrom, W. Quinton, R. J. Granger, and S. Carey, 2007: The cold regions hydrological model: A platform for basing process representation and model structure on physical evidence. Hydrol. Processes, 21, 2650-2667, https://doi.org/10.1002/hyp.6787.

— X. Fang, and C. Ellis, 2012: Sensitivity of snowmelt hydrology in Marmot Creek, Alberta, to forest cover disturbance. Hydrol. Processes, 26, 1891-1904, https://doi.org/10.1002/ hyp.9248.

,-- , and K. Rasouli, 2015: Sensitivity of snow processes to warming in the Canadian Rockies. 72nd Eastern Snow Conf., Sherbrooke, QC, Canada, Easatern Snow Conference, 22-33. ,,- , and D. G. Marks, 2016: The cold rain-on-snow event of June 2013 in the Canadian Rockies-Characteristics and diagnosis. Hydrol. Processes, 30, 2899-2914, https://doi.org/ 10.1002/hyp.10905.

Poulin, A., F. Brissette, R. Leconte, R. Arsenault, and J. S. Malo, 2011: Uncertainty of hydrological modelling in climate change impact studies in a Canadian, snow-dominated river basin. J. Hydrol., 409, 626-636, https://doi.org/10.1016/ j.jhydrol.2011.08.057.

Quinton, W. L., and S. K. Carey, 2008: Towards an energy-based runoff generation theory for tundra landscapes. Hydrol. Processes, 22, 4649-4653, https://doi.org/10.1002/hyp.7164.

— , R. K. Bemrose, Y. Zhang, and S. K. Carey, 2009: The influence of spatial variability in snowmelt and active layer thaw on hillslope drainage for an alpine tundra hillslope. Hydrol. Processes, 23, 2628-2639, https://doi.org/10.1002/hyp.7327.

Rango, A., 1992: Worldwide testing of the snowmelt runoff model with applications for predicting the effects of climate change. Nord. Hydrol., 23, 155-172, https://doi.org/10.2166/ nh.1992.0011.

Rasouli, K., 2017: Sensitivity analysis of mountain hydrology to changing climate. Ph.D. thesis, University of Saskatchewan, $251 \mathrm{pp}$.

J. W. Pomeroy, J. R. Janowicz, S. K. Carey, and T. J. Williams, 2014: Hydrological sensitivity of a northern mountain basin to climate change. Hydrol. Processes, 28, 4191-4208, https://doi.org/10.1002/hyp.10244.

$\longrightarrow,-\frac{1}{\longrightarrow}$, and D. G. Marks, 2015: Snowpack sensitivity to perturbed climate in a cool mid-latitude mountain catchment. Hydrol. Processes, 29, 3925-3940, https://doi.org/10.1002/hyp.10587.

,-- J. R. Janowicz, T. J. Williams, and S. K. Carey, 2019: A long-term hydrometeorological dataset (1993-2014) of a northern mountain basin: Wolf Creek Research Basin, Yukon Territory, Canada. Earth Syst. Sci. Data, 11, 89-100, https:// doi.org/10.5194/essd-11-89-2019.

Rauscher, S. A., J. S. Pal, N. S. Diffenbaugh, and M. M. Benedetti, 2008: Future changes in snowmelt-driven runoff timing over the western US. Geophys. Res. Lett., 35, L16703, https:// doi.org/10.1029/2008GL034424.

Reba, M. L., D. Marks, M. Seyfried, A. Winstral, M. Kumar, and G. Flerchinger, 2011: A long-term data set for hydrologic modeling in a snow-dominated mountain catchment. Water Resour. Res., 47, W07702, https://doi.org/10.1029/ 2010WR010030. 
J. Pomeroy, D. Marks, and T. E. Link, 2012: Estimating surface sublimation losses from snowpacks in a mountain catchment using eddy covariance and turbulent transfer calculations. Hydrol. Processes, 26, 3699-3711, https://doi.org/ 10.1002/hyp.8372.

, D. Marks, T. E. Link, J. W. Pomeroy, and A. Winstral, 2014: Sensitivity of model parameterizations for simulated latent heat flux at the snow surface for complex mountain sites. Hydrol. Processes, 28, 868-881, https://doi.org/10.1002/hyp.9619.

Robertson, A. W., and C. R. Mechoso, 1998: Interannual and decadal cycles in river flows of southeastern South America. J. Climate, 11, 2570-2581, https://doi.org/10.1175/1520-0442(1998) 011<2570:IADCIR >2.0.CO;2.

Running, S. W., and R. R. Nemani, 1991: Regional hydrologic and carbon balance responses of forests resulting from potential climate change. Climatic Change, 19, 349-368, https://doi.org/ 10.1007/BF00151173.

Schär, C., C. Frei, D. Lüthi, and H. C. Davies, 1996: Surrogate climate-change scenarios for regional climate models. Geophys. Res. Lett., 23, 669-672, https://doi.org/10.1029/ 96GL00265.

Semadeni-Davies, A., C. Hernebring, G. Svensson, and L. G. Gustafsson, 2008: The impacts of climate change and urbanisation on drainage in Helsingborg, Sweden: Combined sewer system. J. Hydrol., 350, 100-113, https://doi.org/10.1016/ j.jhydrol.2007.05.028.

Seyfried, M., L. Grant, D. Marks, A. Winstral, and J. McNamara, 2009: Simulated soil water storage effects on streamflow generation in a mountainous snowmelt environment, Idaho, USA. Hydrol. Processes, 23, 858-873, https://doi.org/10.1002/hyp.7211.

Seyyedi, H., E. Anagnostou, E. Beighley, and J. McCollum, 2014: Satellite-driven downscaling of global reanalysis precipitation products for hydrological applications. Hydrol. Earth Syst. Sci., 18, 5077-5091, https://doi.org/10.5194/hess-18-5077-2014.

Sorg, A., T. Bolch, M. Stoffel, O. Solomina, and M. Beniston, 2012: Climate change impacts on glaciers and runoff in Tien Shan (Central Asia). Nat. Climate Change, 2, 725-731, https:// doi.org/10.1038/nclimate1592.

Stewart, I. T., D. R. Cayan, and M. D. Dettinger, 2004: Changes in snowmelt runoff timing in western North America under a 'business as usual' climate change scenario. Climatic Change, 62, 217-232, https://doi.org/10.1023/B:CLIM.0000013702.22656.e8.

Stockton, C. W., and W. R. Boggess, 1979: Geohydrological implications of climate change on water resource development. DTIC Tech. Rep., 206 pp.

Teutschbein, C., and J. Seibert, 2012: Bias correction of regional climate model simulations for hydrological climate-change impact studies: Review and evaluation of different methods. J. Hydrol., 456-457, 12-29, https://doi.org/10.1016/ j.jhydrol.2012.05.052.
Timmermann, A., J. Oberhuber, A. Bacher, M. Esch, M. Latif, and E. Roeckner, 1999: Increased El Niño frequency in a climate model forced by future greenhouse warming. Nature, 398, 694-697, https://doi.org/10.1038/19505.

Tolson, B. A., and C. A. Shoemaker, 2007: Dynamically dimensioned search algorithm for computationally efficient watershed model calibration. Water Resour. Res., 43, W01413, https://doi.org/10.1029/2005WR004723.

Trenberth, K. E., 1990: Recent observed interdecadal climate changes in the Northern Hemisphere. Bull. Amer. Meteor. Soc., 71, 988-993, https://doi.org/10.1175/1520-0477(1990) 071<0988:ROICCI >2.0.CO;2.

Viviroli, D., and R. Weingartner, 2004: The hydrological significance of mountains: From regional to global scale. Hydrol. Earth Syst. Sci., 8, 1017-1029, https://doi.org/10.5194/hess-81017-2004.

Walmsley, J. L., P. A. Taylor, and J. R. Salmon, 1989: Simple guidelines for estimating windspeed variations due to smallscale topographic features-an update. Climatol. Bull., 23 (1), 3-14.

Wang, J. Y., P. H. Whitfield, and A. J. Cannon, 2006: Influence of Pacific climate patterns on low-flows in British Columbia and Yukon, Canada. Can. Water Resour. J., 31, 25-40, https:// doi.org/10.4296/cwrj3101025.

Whitfield, P. H., and A. J. Cannon, 2000: Recent variations in climate and hydrology in Canada. Can. Water Resour. J., 25, 19-65, https://doi.org/10.4296/cwrj2501019.

Wilcoxon, F., 1945: Individual comparisons by ranking methods. Biom. Bull., 1, 80-83, https://doi.org/10.2307/3001968.

Williams, T. J., J. W. Pomeroy, J. R. Janowicz, S. K. Carey, K. Rasouli, and W. L. Quinton, 2015: A radiative-conductiveconvective approach to calculate thaw season ground surface temperatures for modelling frost table dynamics. Hydrol. Processes, 29, 3954-3965, https://doi.org/10.1002/hyp.10573.

Winstral, A., and D. Marks, 2014: Long-term snow distribution observations in a mountain catchment: Assessing variability, time stability, and the representativeness of an index site. Water Resour. Res., 50, 293-305, https://doi.org/10.1002/ 2012WR013038.

_,$\ldots$, and R. Gurney, 2013: Simulating wind-affected snow accumulations at catchment to basin scales. Adv. Water Resour., 55, 64-79, https://doi.org/10.1016/j.advwatres.2012.08.011.

Wood, A. W., L. R. Leung, V. Sridhar, and D. P. Lettenmaier, 2004: Hydrologic implications of dynamical and statistical approaches to downscaling climate model outputs. Climatic Change, 62, 189216, https://doi.org/10.1023/B:CLIM.0000013685.99609.9e.

Wunsch, C., 1999: The interpretation of short climate records, with comments on the North Atlantic and Southern Oscillations. Bull. Amer. Meteor. Soc., 80, 245-255, https://doi.org/10.1175/ 1520-0477(1999)080<0245:TIOSCR>2.0.CO;2. 